\title{
Episodic crustal growth in the Bundelkhand craton of central India shield: Constraints from petrogenesis of the tonalite-trondhjemite-granodiorite gneisses and K-rich granites of Bundelkhand tectonic zone
}

\author{
Hiredya Chauhan, Ashima Saikia* and Talat Ahmad \\ University of Delhi, Delhi 110 00\%, India. \\ *Corresponding author. e-mail: ashima.saikia@gmail.com
}

MS received 19 April 2017; revised 6 July 2017; accepted 13 August 2017; published online 12 April 2018

Tonalite-trondhjemite-granodiorite gneisses (TTG) and K-rich granites are extensively exposed in the Mesoarchean to Paleoproterozoic Bundelkhand craton of central India. The TTGs rocks are coarsegrained with biotite, plagioclase feldspar, K-feldspar and amphibole as major constituent phases. The major minerals constituting the K-rich granites are K-feldspar, plagioclase feldspar and biotite. They are also medium to coarse grained. Mineral chemical studies show that the amphiboles of TTG are calcic amphibole hastingsite, plagioclase feldspars are mostly of oligoclase composition, K-feldspars are near pure end members and biotites are solid solutions between annite and siderophyllite components. The K-rich granites have biotites of siderophyllite-annite composition similar to those of TTGs, plagioclase feldspars are oligoclase in composition, potassic feldspars have $\mathrm{X}_{\mathrm{K}}$ ranging from 0.97 to 0.99 and are devoid of any amphibole. The tonalite-trondhjemite-granodiorite gneiss samples have high $\mathrm{SiO}_{2}(64.17-$ 74.52 wt\%), $\mathrm{Na}_{2} \mathrm{O}$ (3.11-5.90 wt\%), low $\mathrm{Mg} \#(30-47)$ and HREE contents, with moderate $(\mathrm{La} / \mathrm{Yb})_{\mathrm{CN}}$ values (14.7-33.50) and $\mathrm{Sr} / \mathrm{Y}$ ratios (4.85-98.7). These geochemical characteristics suggest formation of the TTG by partial melting of the hydrous basaltic crust at pressures and depths where garnet and amphibole were stable phases in the Paleo-Mesoarchean. The K-rich granite samples show high $\mathrm{SiO}_{2}$ (64.72-76.73 wt\%), $\mathrm{K}_{2} \mathrm{O}$ (4.31-5.42), low $\mathrm{Na}_{2} \mathrm{O}$ (2.75-3.31 wt\%), $\mathrm{Mg} \#$ (24-40) and $\mathrm{HREE}$ contents, with moderate to high $(\mathrm{La} / \mathrm{Yb})_{\mathrm{CN}}$ values $(9.26-29.75)$ and $\mathrm{Sr} / \mathrm{Y}$ ratios $(1.52-24)$. They differ from their TTG in having elevated concentrations of incompatible elements like K, Zr, Th, and REE. These geochemical features indicate formation of the K-granites by anhydrous partial melting of the PaleoMesoarchean TTG or mafic crustal materials in an extensional regime. Combined with previous studies it is interpreted that two stages of continental accretion (at 3.59-3.33 and 3.2-3.0 Ga) and reworking (at 2.5-1.9 Ga) occurred in the Bundelkhand craton from Archaean to Paleoproterozoic.

Keywords. Tonalite-trondjemite-granodiorite gneiss; K-rich granites; Bundelkhand craton; subduction; continental crust; central Indian shield.

\section{Introduction}

The continental crust holds the key to the record of how processes of crust generation have evolved through geologic time and preserves evidence of secular variation in crustal composition. One way of deciphering the primitive crustal composition and its evolution through time is to study the 
petrological and geochemical attributes of the various rock types preserved in Archaean cratons as the Archaean period is known to represent nearly one-third of the Earth's early history.

Archaean cratons are known to be dominated by four major types of rock associations with distinct chemical signatures namely (a) Tonalitetrondhjemite-granodiorite (TTG) suite are characterized by Na-enrichment $\left(\mathrm{Na}_{2} \mathrm{O} / \mathrm{K}_{2} \mathrm{O}>1\right)$, $\mathrm{Al}_{2} \mathrm{O}_{3}>15$ wt $\%, \mathrm{Mg} \#=0.43-0.51, \mathrm{Cr}=29 \mathrm{ppm}$, $\mathrm{Sr}>400 \mathrm{ppm}$, and low HREE $(\mathrm{Y}<15 \mathrm{ppm}$, $\mathrm{Yb}<1.6 \mathrm{ppm})$ which result in high $\mathrm{Sr} / \mathrm{Y}>40$ and strongly fractionated $\mathrm{REE}\left(\mathrm{La} / \mathrm{Yb}_{\mathrm{CN}}=\right.$ 15-100) (e.g., Martin 1999; Martin and Moyen 2005), (b) Sanukitoids are characterized by $\mathrm{SiO}_{2}=$ 55-70 wt $\%, \quad \mathrm{Na}_{2} \mathrm{O} / \mathrm{K}_{2} \mathrm{O}=0.5-3, \quad \mathrm{MgO}=$ $1.5-9 \mathrm{wt} \%, \mathrm{Mg} \#=45-65, \mathrm{~K}_{2} \mathrm{O}=1.5-5.0 \mathrm{wt} \%$, $\mathrm{Ba}+\mathrm{Sr}=1400 \mathrm{ppm}$ and $(\mathrm{Gd} / \mathrm{Er})_{\mathrm{CN}}=2-6$ (e.g., Smithies and Champion 2000; Moyen et al. 2003a, b; Kovalenko et al. 2005; Lobach-Zhuchenko et al. 2008; Halla et al. 2009; Heilimo et al. 2010; Oliveria et al. 2010), (c) the leucocratic, peraluminous granitoids are rich in incompatible elements $\mathrm{Rb}$ and $\mathrm{Th}, \mathrm{Na}_{2} \mathrm{O} / \mathrm{K}_{2} \mathrm{O}<0.5$, moderately fractionated $\mathrm{REE}(\mathrm{La} / \mathrm{Yb})_{\mathrm{CN}}<30$ with strong $\mathrm{Eu}$ anomaly (Moyen et al. 2003a,b) and (d) K-rich granites are biotite bearing and are characterized by $\mathrm{Na}_{2} \mathrm{O} / \mathrm{K}_{2} \mathrm{O}<1$, moderately fractionated $\mathrm{REE}$ patterns $(\mathrm{La} / \mathrm{Yb})_{\mathrm{CN}}<30$ (Sylvester 1994; Manya et al. 2007).

Of these rock associations, the tonalitictrondhjemitic-granodioritic rocks and the greenstone belts are considered to be the best proxy to Archaean mantle as they represent $60-80 \%$ of the exposed Archaean crust. They occur mainly as basement to the greenstone belts although they may occasionally occur as syn-to post-tectonic plutons (Champion and Smithies 1999). The K-rich granites represent the second abundant Archaean rock type constituting $\sim 20 \%$ of the exposed Archaean crust and in many cratons; they appear to have formed later than the TTG in the late Archaean (Sylvester 1994). Indian shield is one of the many significant sites in the world, which preserves the records of the evolution and the growth history of the early Archaean-Palaeoproterozoic crust. The peninsular shield region of India is known to consists of several Archaean cratons which has TTG occurrences, viz., the Bundelkhand craton in the northern India (Mondal et al. 2002), the Singhbhum craton in the east India (Upadhyay et al. 2014), the Bastar craton inthe central part of India (Ghosh 2004) and the Dharwar craton in the southern part (Jayananda et al. 2015) (figure 1a).

In the Bundelkhand craton the TTG and K-rich granites are reported from the Bundelkhand Gneissic Complex which is considered to be the oldest litho-unit of this craton (Mondal et al. 2002; Singh et al. 2007) (figure 1b). The evolutionary history and tectonic processes responsible for cratonisation of the Bundelkhand need to be well constrained for any hypothesized position of India in Precambrian supercontinent reconstruction. In this paper, we present for the first time mineral chemical data and new geochemical data for petrographically wellconstrained TTG and K-rich granites from the Bundelkhand Tectonic Zone of the central part of the Bundelkhand craton to infer its petrogenesis for a better understanding of the crustal and tectonic evolution of the peninsular shield region of India during Archaean to Palaeoproterozoic.

\section{Geologic setting}

Although the Precambrian crustal evolution of the Bundelkhand craton is not robustly constrained, it is broadly agreed that the Precambrian basement of the Bundelkhand craton is a result of amalgamation of many micro-blocks (Sharma 2009; Mohan et al. 2012). Naqvi and Rogers (1987) proposed that the Great Boundary Fault divides this protocontinent into two blocks, viz., the Aravalli cratonic block to the east and the Bundelkhand-Gwalior cratonic block to the west.

The Bundelkhand-Gwalior cratonic block is a semi-circular massif spread over an area of about $29,000 \mathrm{~km}^{2}$ (Basu 1986) (figure 1b). Sharma and Rahman (2000) proposed three distinct lithostratigraphic units for the block namely, (a) the Archaean enclaves of highly deformed older gneisses-greenstone components (3.59-2.6 Ga) (Sarkar et al. 1984; Mondal et al. 2002; Kaur et al. 2014; Saha et al. 2016; Verma et al. 2016; Joshi et al. 2016), (b) the early Proterozoic undeformed multiphase granitoid plutons (2.5-2.1) (Crawford 1970; Sarkar et al. 1984; Mondal et al. 2002; Verma et al. 2016; Joshi et al. 2016; Kaur et al. 2016) and (c) lastly the younger mafic dyke swarms (Basu 1986, 2001; Pradhan et al. 2012).

Various workers based on geochemical and geochronological study on basalts, komatiites, TTG and younger granitoids have proposed an arcrelated subduction setting for generation of various litho-assemblages reported from the Bundelkhand 


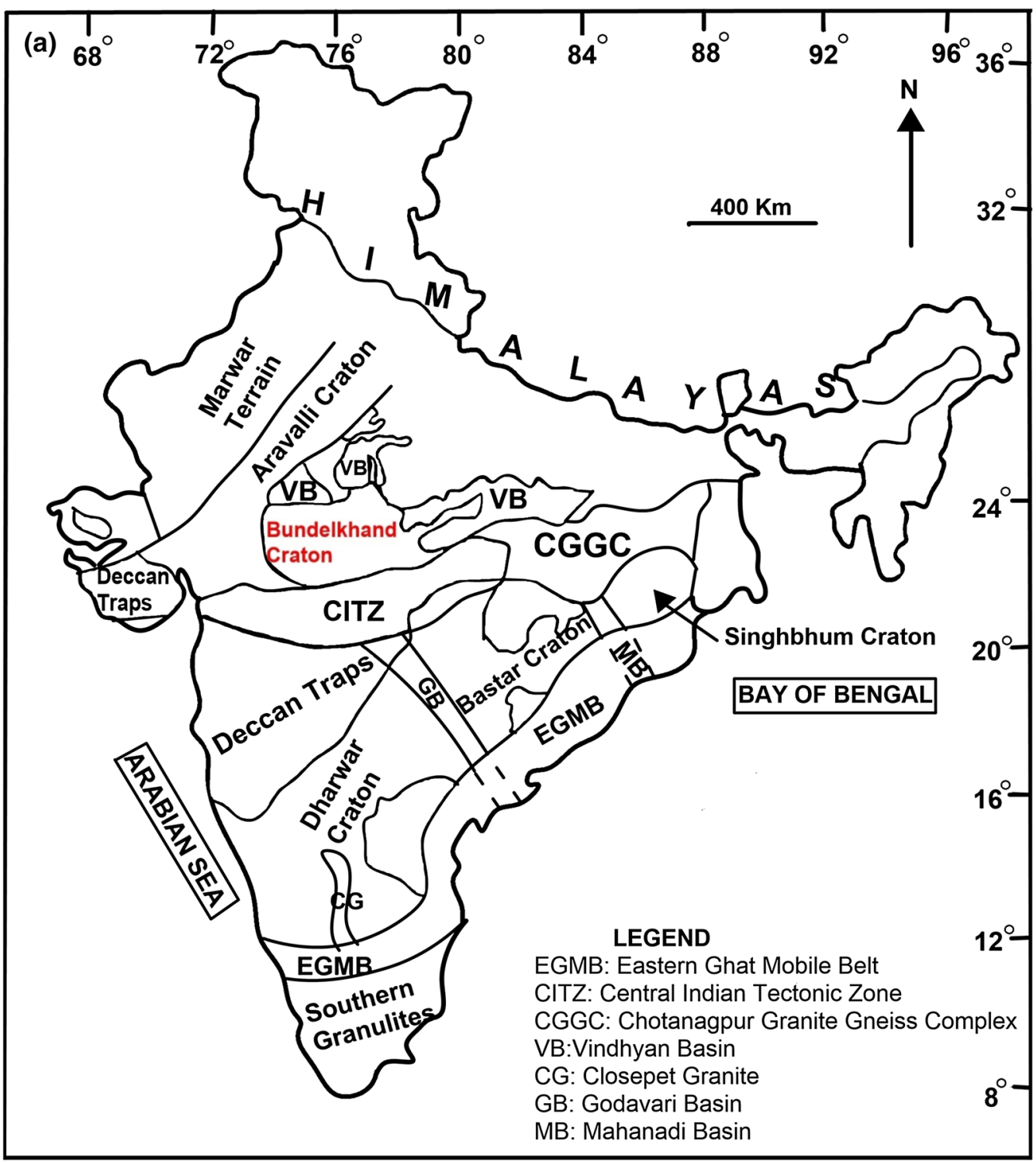

Figure 1. (a) Map of India showing the relative position of the Bundelkhand craton with respect to various cratons of the Indian shield (modified after Pradhan et al. 2009). (b) Geological map of the Bundelkhand craton (reproduced after Basu 1986). Granitoid magmatism ages reported by various authors are displayed on the map (Mondal et al. 2002; Kaur et al. 2014, 2016; Joshi et al. 2016). (c) Detailed geological map of the Bundelkhand Tectonic Zone showing the various litho units reported from the area. Marked on it are the sample locations of the TTGs and K-rich granites of the present study.

craton (Mondal et al. 1998, 2002; Singh et al. 2007; Malviya et al. 2006; Kumar et al. 2011; Mohan et al. 2012). Age of the TTG gneisses reported from the Bundelkhand craton range is from 3.59 to $2.66 \mathrm{Ga}$ (Mondal et al. 2002; Kaur et al. 2014, 2016; Verma et al. 2016; Saha et al. 2016; Joshi et al. 2016). Crawford (1970), Roy and Kröner (1996), Mondal et al. (1998, 2002) and Meert et al. (2011) have proposed that multiphase K-rich granite magmatism (2.55-2.69) marks the cratonization of the Bundelkhand craton. It has been suggested that in subduction derived magmatism granitoids may differentiate into two types: one bearing high Ca resulting in the TTG formation and the other bearing low Ca resulting K-rich granites. The high Ca granitoids are generally trondhjemites and tonalities derived due to partial melting of a depleted basaltic source and the K-rich granites are mostly derived through partial melting of the felsics associated with older TTGs (Champion and Sheraton 1997). Hence, the Archaean enclaves of gneisses and greenstones and the younger granitoids intruding the pre-existing greenstone gneiss assemblage of Bundelkhand craton provide the ideal rock types to investigate the Precambrian crustal evolution of the peninsular Indian Shield. 


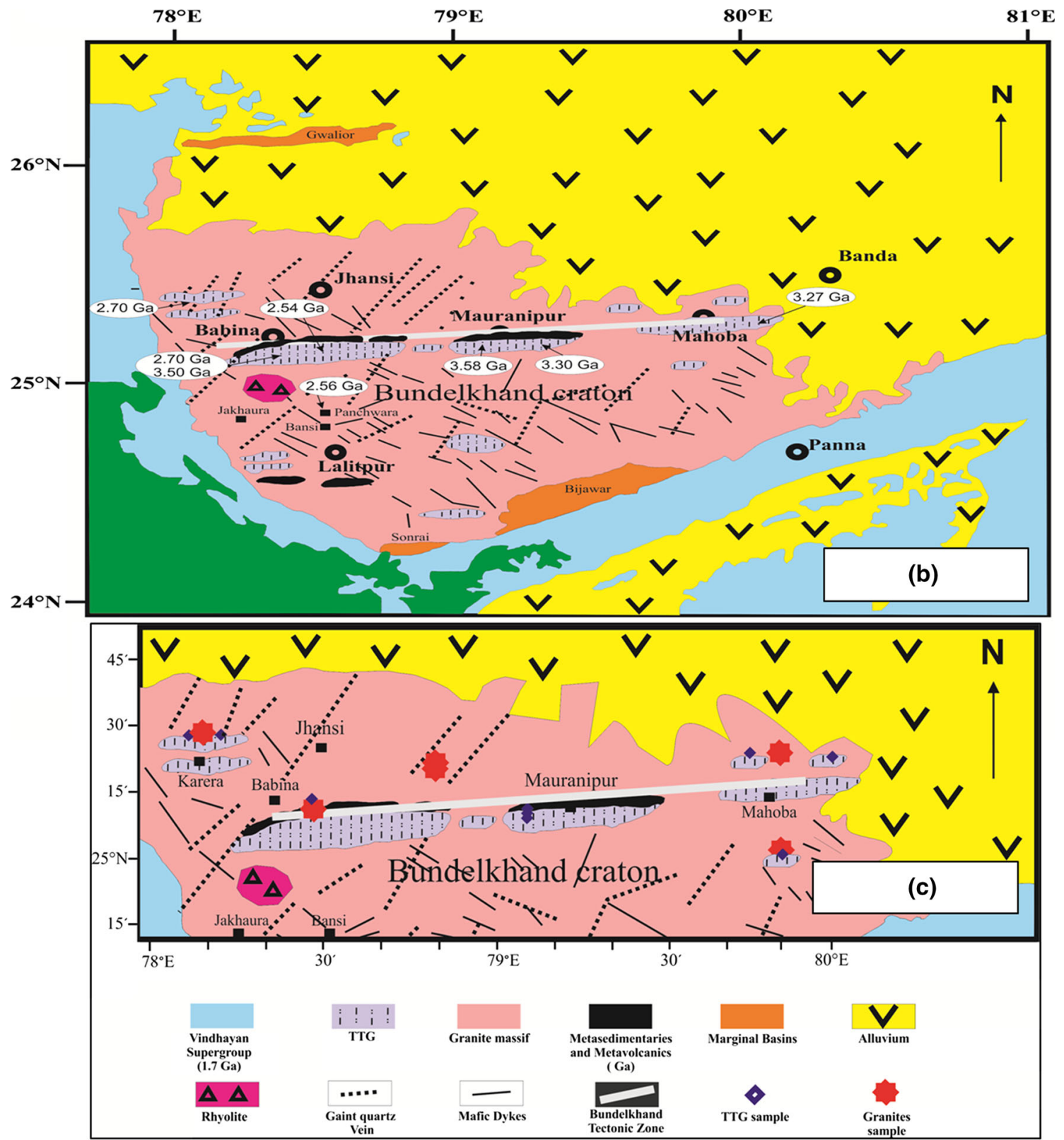

Figure 1. (Continued.)

\section{Sampling and petrography}

\subsection{Sampling}

The TTGs are exposed along the E-W striking Bundelkhand Tectonic Zone (a major shear zone) extending along N2515" (Pati 1999). The tectonic zone extends along the strike of around $200 \mathrm{~km}$ from Mahoba through Mauranipur to Babina (figure 1a). This belt consists of metavolcanics and minor sedimentary components in association with the TTG gneisses. The TTG gneisses are exposed along this zone from different areas including Mahoba, Kabrai, Kuraicha and Babina.
K-rich granite occurrences are sporadic and are found associated with this belt. The TTGs show evidence of three generations of folds related to three deformation events and the foliation generally strikes NW-SE with north-easterly or southwesterly dips $\left(60^{\circ}-70^{\circ}\right)$ (Singh et al. 2007). There is a sharp contact between the TTG and granites. The TTG samples are generally medium to coarse-grained and are leucocratic to mesocratic. Well-developed gneissosity of variable thickness of mafic and felsic minerals are prominently observed for TTG samples.

Samples for this study were collected from road sections where fresh rocks are best exposed. A total 

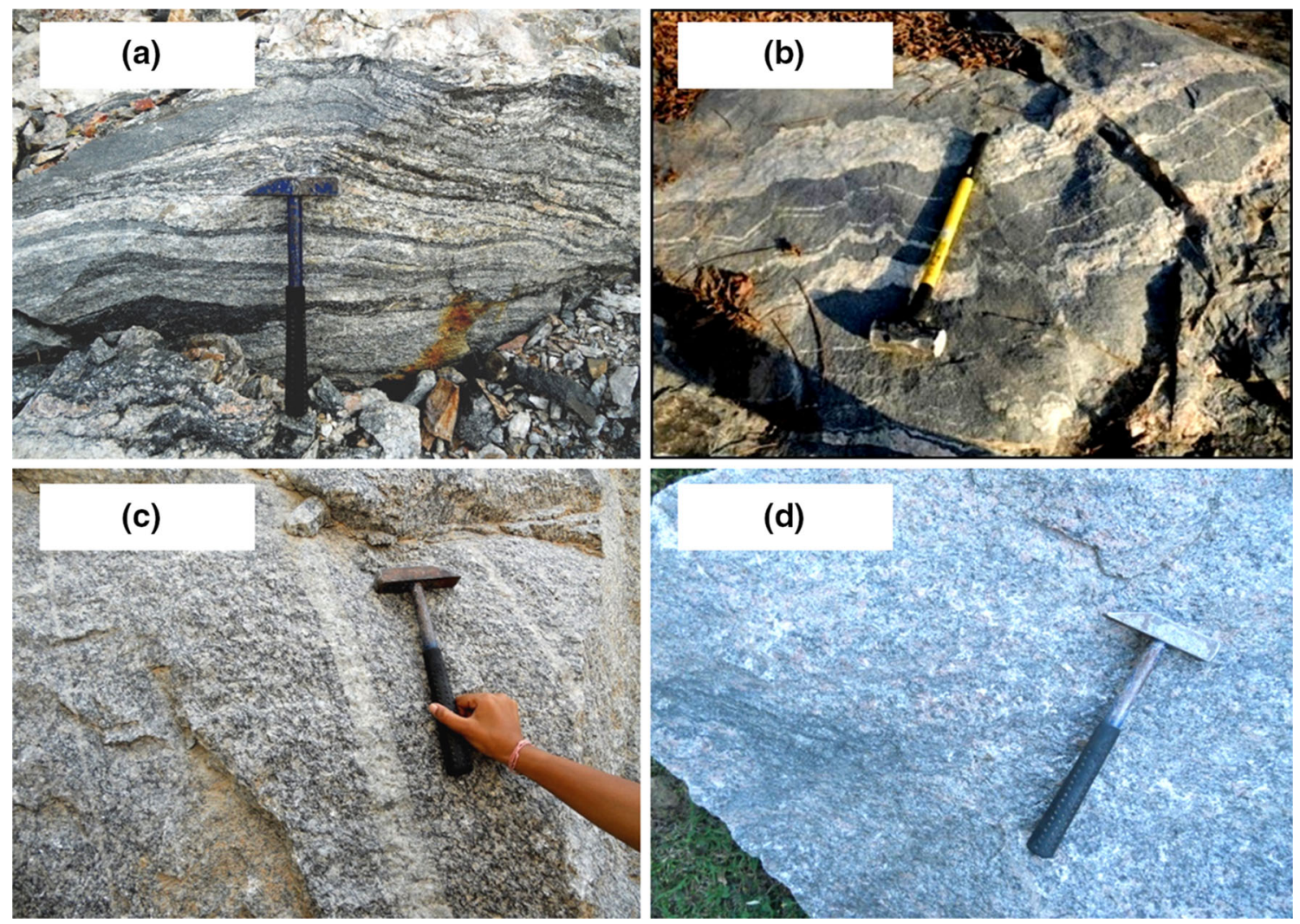

Figure 2. Field photographs (a, b) outcrops of tonalite-trondhjemite-granodiorite gneisses with well-developed gneissic foliation, (b, c) K-rich granites; one on the left showing a weak gneissic foliation and other with no visible gneissic foliation.

of 59 samples (36 TTG and 23 K-rich granites) were collected for laboratory analysis. Sample locations are marked in figures $1(\mathrm{c})$ and $2(\mathrm{a}, \mathrm{b})$ which show field outcrops of TTG and figure 2(c, d) shows K-rich granites.

\subsection{Petrography}

Representative samples of both TTGs and K-rich granites were made into thin sections and studied under polarizing microscope.

\subsection{TTGs}

They are composed of plagioclase (21 vol\%), quartz (45 vol\%), biotite (15 vol\%), amphibole (hasting site) (4 vol\%) and K-feldspar (15 vol\%). Accessory phases observed include titanite, epidote, apatite, monazite and zircon (1 vol\%) (figure $3 \mathrm{a}-\mathrm{d}$ ).

Plagioclases occur as small to large sized grains with anhedral to subhedral form and are identified by low relief, first order grey interference colour and lamellar twinning. Sieved plagioclase texture is also present. Plagioclase is partly altered to sericite due to late hydrothermal alteration. Quartz occurs as medium to large sized grains showing anhedral to subhedral form. Undulose extinction is common. Biotite shows light brown colour and pleochroism from light brown to dark brown. It occurs as medium to large sized grains with anhedral to subhedral form. Alteration of biotite grains to chlorite is observed in few sections, amphiboles are medium grained and are subhedral in form. In few sections, amphibole is seen altering to biotite which at places is seen replaced by chlorite. Samples also show occurrence of anhedral K-feldspar/microcline. TTGs show typical gneissic fabric with parallel layering and alignment of plagioclase, quartz, amphibole and biotite.

\subsection{K-rich granites}

They are characterised by K-feldspar and mostly are granitic gneisses according to the field and petrographic characteristics. The mineral assemblage mainly consists of K-feldspar (29 vol\%), plagioclase (20 vol\%), biotite (7 vol\%) and quartz (43 vol\%). Zircon, epidote and apatite are the common accessory minerals (1 vol\%) (figure 3e, f). These rocks show weak gneissic layering of biotite alternating 

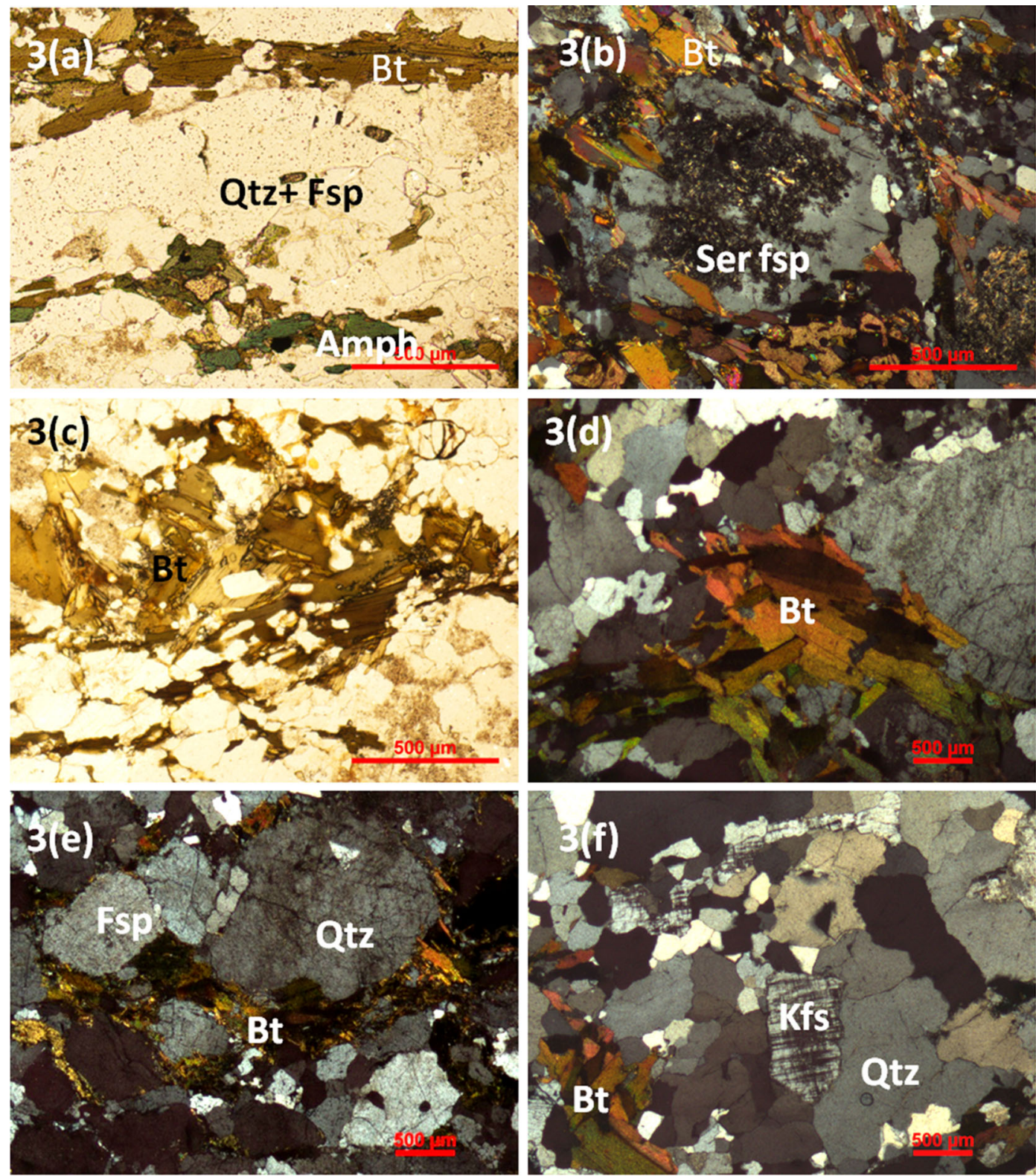

Figure 3. Photomicrographs displaying (a-d) assemblage of biotite (Bt), plagioclase feldspar (Fsp), quartz (Qtz) and amphibole (Amph), sericitised feldspars (Ser Fsp) of TTGs from the Bundelkhand suite. Amphiboles and biotites are forming alternate bands with feldspar and quartz rich layers. (e, f) K-rich granites of the Bundelkhand craton with characteristic assemblage of biotite (Bt), K-feldspar (Kfsp), and plagioclase feldspar (Fsp). Grain sizes are coarser than that of the TTGs.

with K-feldspar, quartz and plagioclase. The proportion of K-feldspar is more relative to the TTGs.

Plagioclase and K-feldspar occur as subhedral to anhedral grains of varying sizes. Cross-hatch twining is prominent in the K-feldspars. Plagioclase feldspars commonly show alteration to sericite. Biotite is occurring as lath-shaped grains aligned along the foliation plane alternating with the quartz and feldspar bearing layer. At places they are found surrounding the plagioclase grain boundary as well. No alteration of biotite to chlorite is observed in the granites. The quartz grains are anhedral and are coarse to medium grained.

\section{Mineral chemistry}

\subsection{Analytical technique}

Mineral chemical analyses of various minerals in the TTGs and K-granites were carried out on 
polished thin sections using a CAMECA SX 5 electron microprobe with acceleration voltage of $15 \mathrm{kV}$ and beam current of $20 \mathrm{nA}$ at the Electron Microprobe Analyzer Laboratory, Department of Earth Science, Indian Institute of Technology, Bombay. Analyses were carried out with a beam diameter of $0 \mu \mathrm{m}$ for all phases except Na-rich plagioclase for which it was $5 \mu \mathrm{m}$. Standards used include Rhodonite for $\mathrm{Mn}, \mathrm{TiO}_{2}$ for $\mathrm{Ti}$, Albite for $\mathrm{Na}, \mathrm{Al}_{2} \mathrm{O}_{3}$ for $\mathrm{Al}, \mathrm{Fe}_{2} \mathrm{O}_{3}$ for $\mathrm{Fe}$, Diposide for $\mathrm{Ca}$ and $\mathrm{Mg}$, Orthoclase for $\mathrm{K}$, Apatite for $\mathrm{P}$ and $\mathrm{F}$, $\mathrm{CrO}_{3}$ for $\mathrm{Cr}, \mathrm{NaCl}$ for $\mathrm{Cl}, \mathrm{BaSO}_{4}$ for $\mathrm{Ba}, \mathrm{ZnS}$ for $\mathrm{Zn}$ and Th glass for Si. The ZAF correction was applied to the data.

Electron microprobe data of feldspars, biotite and amphibole together with the calculated number of ions per unit cell are given in table 1 . Representative back scattered electron images of each rock type are shown with characteristic assemblage in figure 4 .

The TTGs and K-granites both have plagioclase and alkali feldspar. Figure 5(a, b) shows a composition plot with feldspar chemistry in terms of Albite-Anorthite-Alkali feldspar for the TTGs and K-granites. Plagioclases in the TTGs are mainly oligoclase with $\mathrm{X}_{\mathrm{Ab}}$ contents of $0.70-0.80$ and $\mathrm{X}_{\mathrm{An}}$ varying from 0.18 to 0.28 . The $\mathrm{K}$-feldspars of TTGs show $\mathrm{X}_{\mathrm{K}}$ value ranging from 0.96 to 0.97 . Plagioclases in the $\mathrm{K}$-granites are mainly oligoclase with $\mathrm{X}_{\mathrm{Ab}}$ contents of $0.73-0.80$ and $\mathrm{X}_{\mathrm{An}}$ varying from 0.18 to 0.25 . We have $\mathrm{K}-\mathrm{Na}$ feldspar as well with $\mathrm{X}_{\mathrm{Ab}}$ content of 0.61 and $\mathrm{X}_{\mathrm{K}}$ content of 0.35 . The K-feldspars of potassic granites show $\mathrm{X}_{\mathrm{K}}$ value ranging from 0.97 to 0.99 .

Biotite compositions of the TTGs and K-granites from this area are representative of the siderophyllite-annite end members (figure 6a). The biotites of TTG display high FeO contents (24$25 \%), \mathrm{TiO}_{2}$ contents $(0.31-2.15 \%)$ and high $\mathrm{Fe} /(\mathrm{Fe}+\mathrm{Mg})$ ratios $(>0.6)$, whereas the biotites of the K-rich granites display $\mathrm{FeO}$ content varying from $(25-27 \%), \mathrm{TiO}_{2}$ content displays a range from 1.61 to $2.94 \%$ and high $\mathrm{Fe} /(\mathrm{Fe}+\mathrm{Mg})$ ratios $(>0.6)$. In the plot of $\mathrm{Mg}$ vs. total Al plot of Abdel-Rahman (1994) (figure 6b), all biotite data of the K-granites fall in subalkaline field, whereas the TTG biotites range from alkaline to subalkaline type.

The amphiboles are only present in TTGs of the Bundelkhand craton. The amphiboles are generally $\mathrm{Al}$ rich (Al total ranges from 1.89 to 2.14) and exhibit $\mathrm{Fe} / \mathrm{Fe}+\mathrm{Mg}$ ratios ranging from 2.14 to 3.90. These minerals belong to the calcic amphibole sub-group. Using the classification of Leake et al.
(1997), the amphiboles are classified as hastingsite (figure 7). Crystallization of amphibole affects the composition of the derivative melt during magmatic differentiation. We have applied geobarometers based on $\mathrm{Al}$ in Hornblende equilibrated with quartz by Hammerstrom and Zen (1986); Hollister et al. (1987) for the TTGs of Bundelkhand. The results show the TTG crystallization pressure to be 4.9-6.8 kbar based on the equation of Hammerstrom and Zen (1986) with an average of $5.94 \mathrm{kbar}$ whereas the Hollister et al. (1987) geobarometer gave a pressure range of 5.1-7.4 kbar (average $=$ $6.30 \mathrm{kbar}$ ). Calculated temperatures for the TTG gneisses using geothermometer of Blundy and Holland (1990) range from 755 to $777^{\circ} \mathrm{C}$ (average $=$ $767^{\circ} \mathrm{C}$ ) using the pressures calculated by Hammerstrom and Zen (1986). Temperatures vary slightly $751-770^{\circ} \mathrm{C}$ (average $=762^{\circ} \mathrm{C}$ ), if pressures calculated by Hollister et al. (1987) are used for temperature calculation (table 2).

\section{Geochemistry}

\subsection{Analytical technique}

Analysis of major oxides and trace elements for TTG samples and K-rich granites was carried out using the XRF technique (Bruker S8 Tiger Sequential X-ray Spectrometer with Rh excitation source) following the procedure of Saini et al. (1998, 2000) and rare earth elements (REE) were analysed using ICP-MS (Perkin Elmer made SCIEX quadrupole type ICP-MS, ELAN DRC-e), at the Wadia Institute of Himalayan Geology, Dehradun (India). For the major oxides the operating conditions were No filter, Vacuum path, 20/40 KV; for trace elements the operating conditions were No filter, Vacuum path, 55/60 KV. The overall accuracy in relative standard deviation percentage is $<5 \%$ for major and minor oxides and $<12 \%$ for the trace elements. The average precision is better than 2.0\% (Purohit et al. 2006; Saini et al. 2007). Sample solutions were introduced for rare earth element analysis into the argon plasma using a peristaltic pump and a cross flow nebulizer. The procedures adopted for sample digestion and preparation of solutions were that of Balaram et al. (1990). USGS (BHVO-1, AGV-1) and JGS (JG-2, RGM-1) samples were used as rock standards to minimize matrix effect. Relative standard deviation (RSD) for most of the samples is better than $10 \%$. Representative major and trace element compositions of 10 TTGs and $10 \mathrm{~K}$-rich 


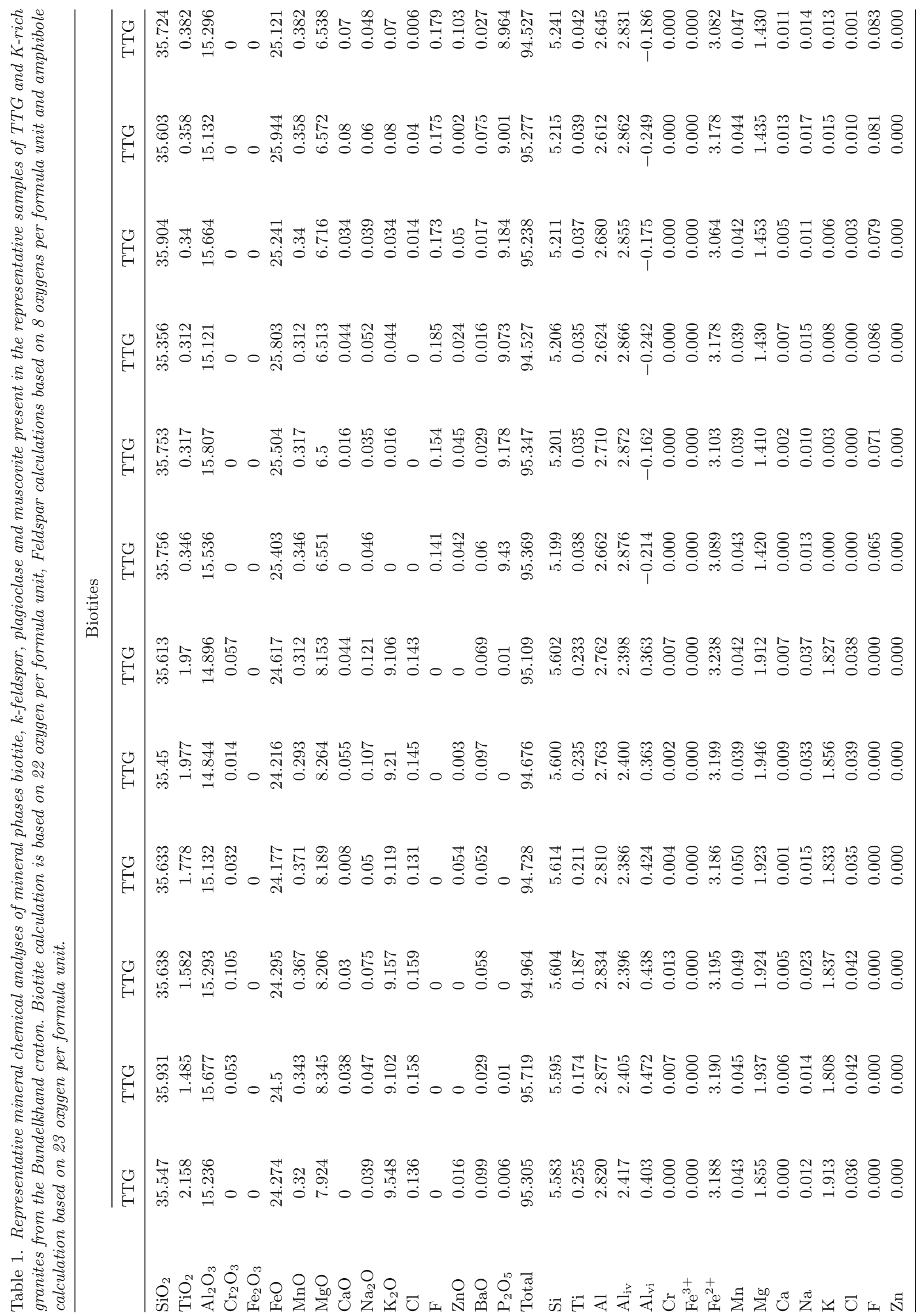




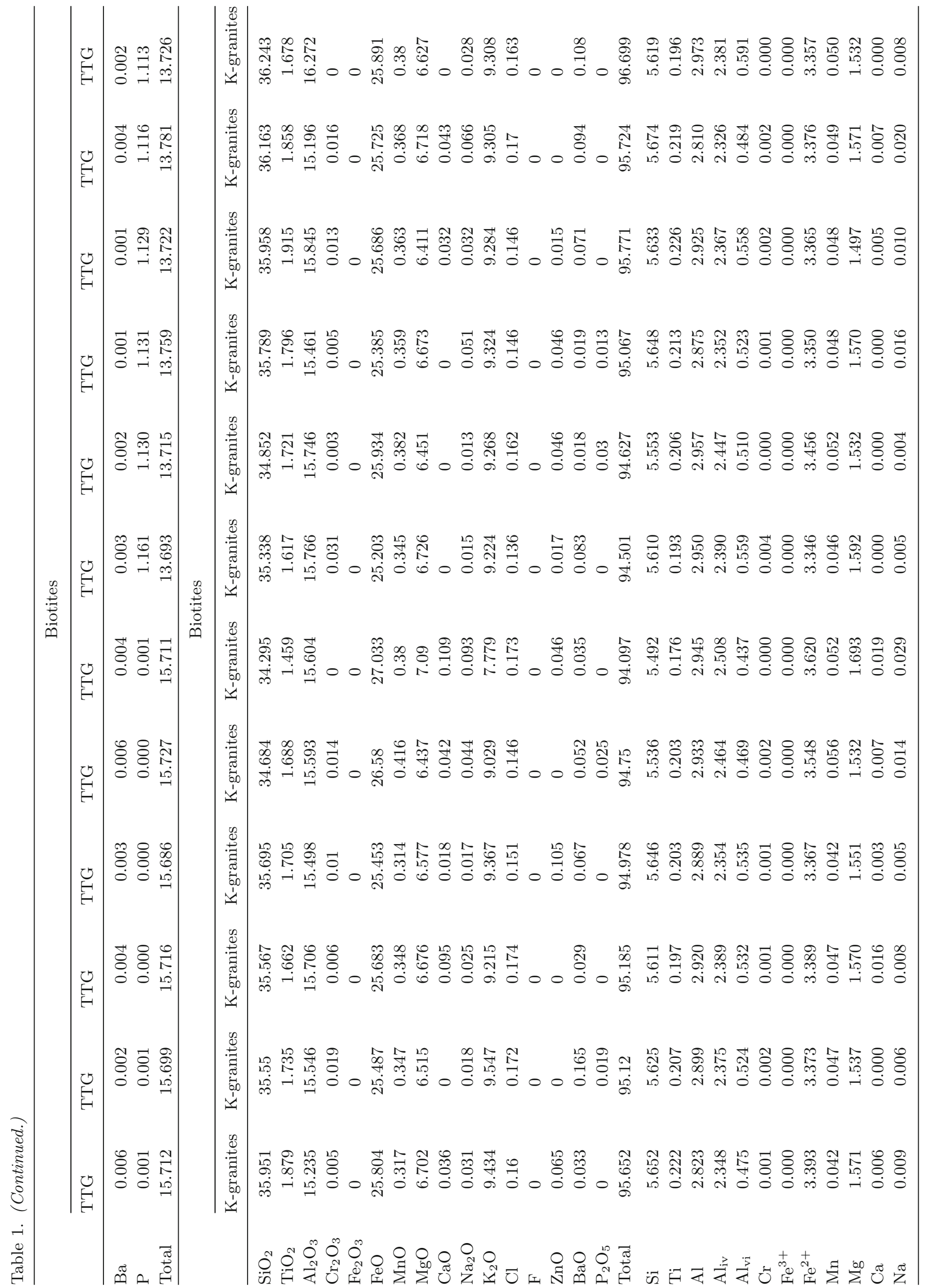




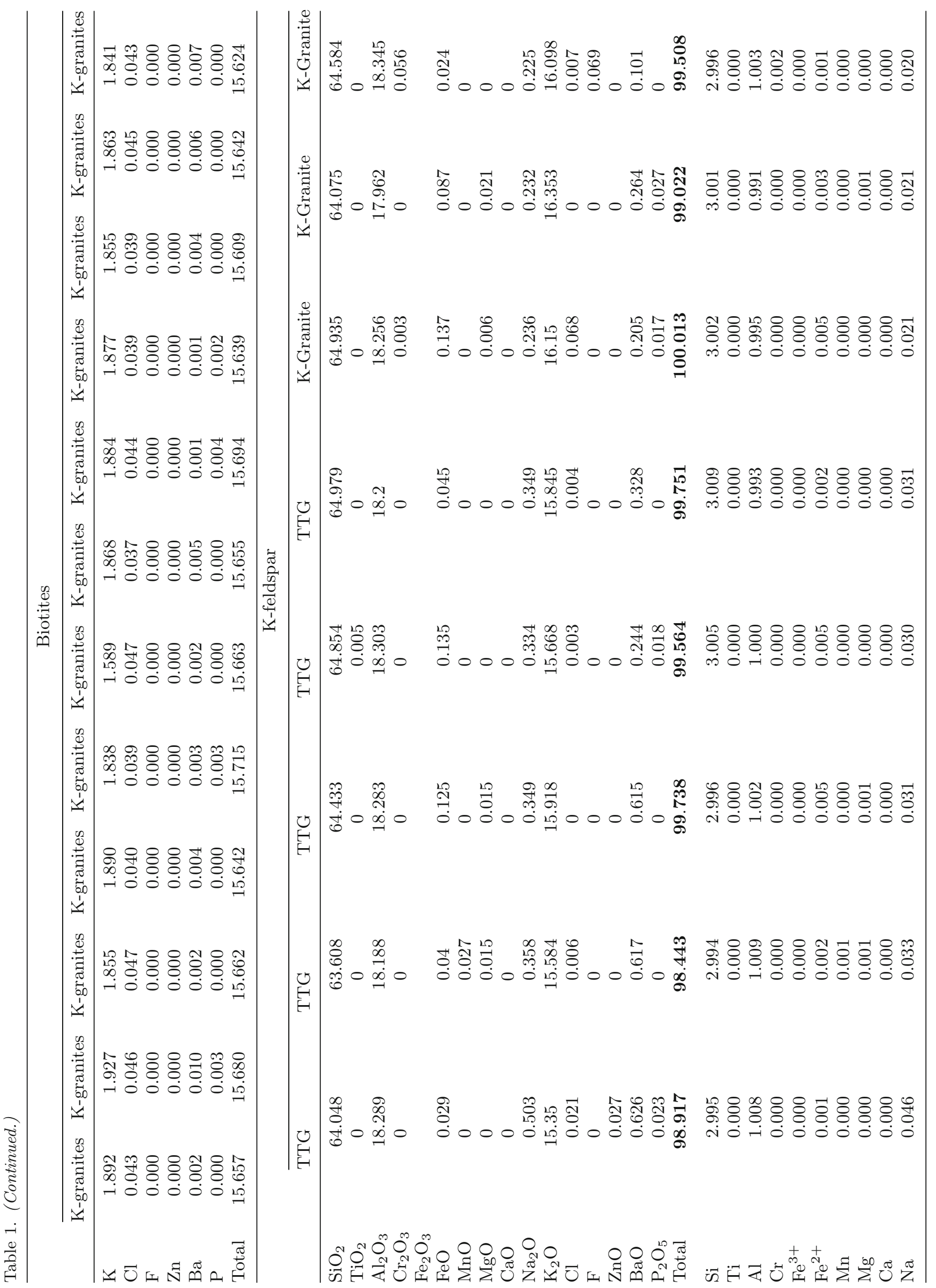




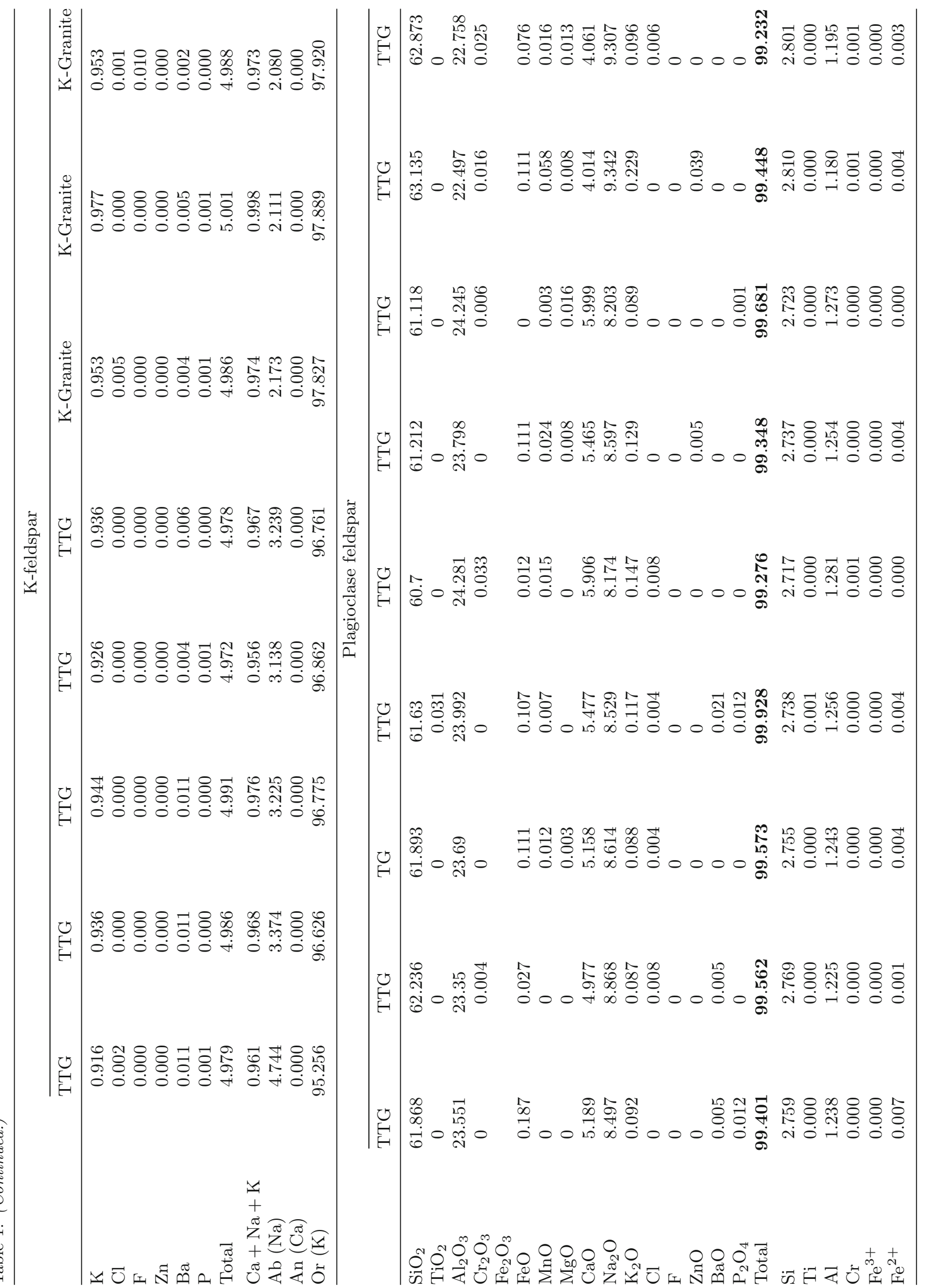




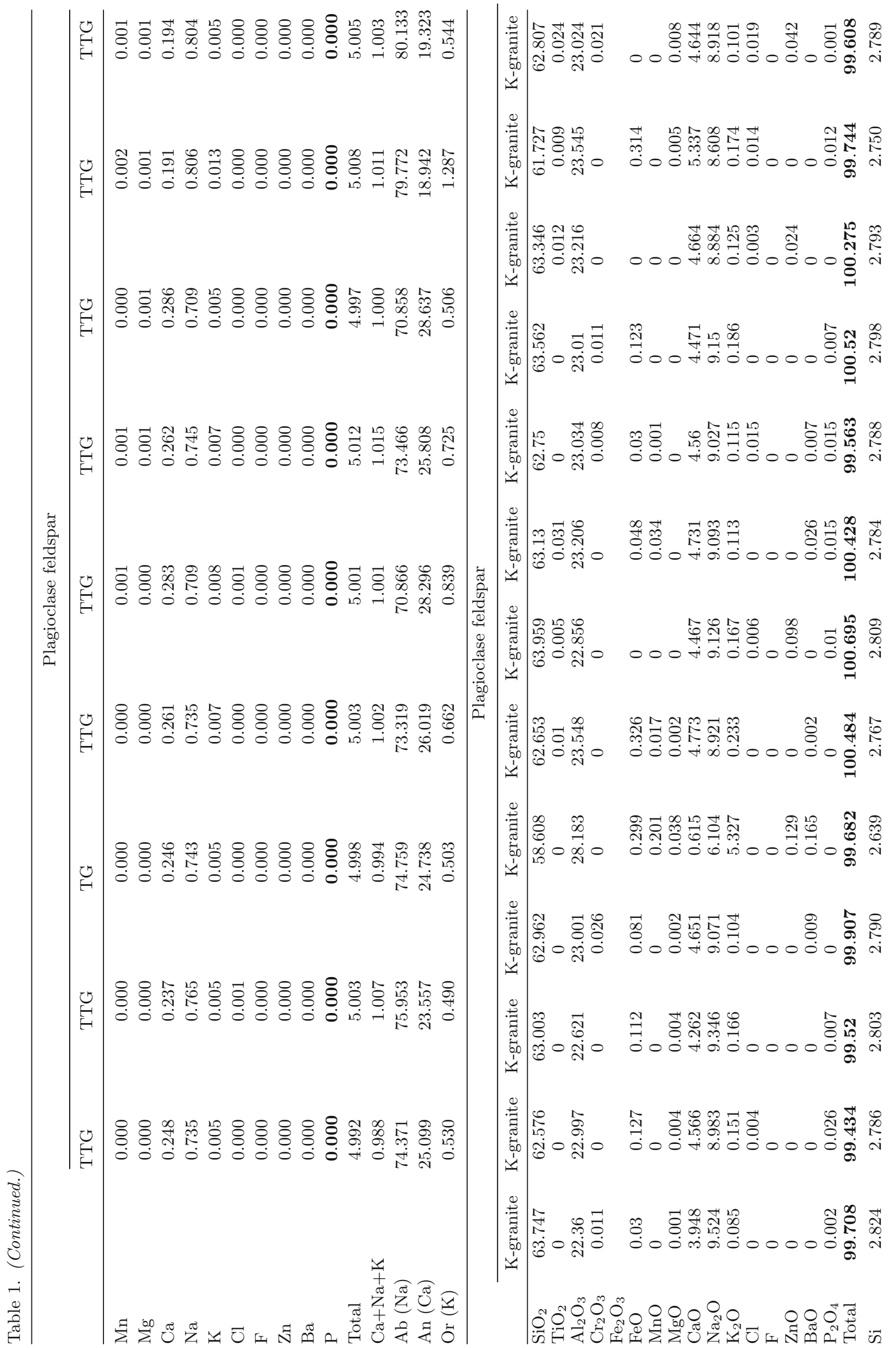




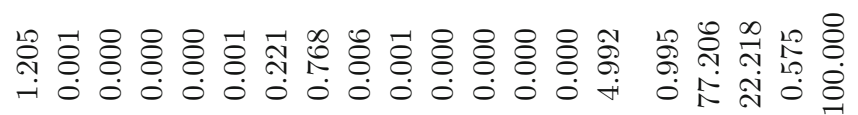
虽 \&

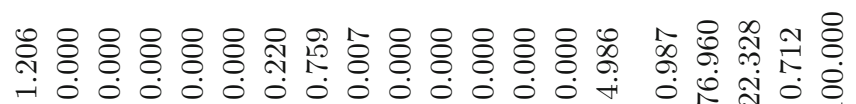

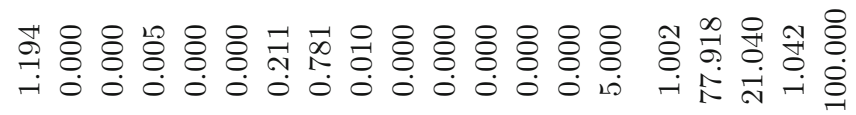

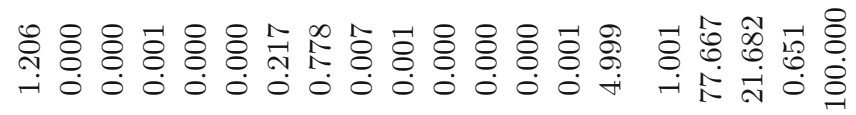

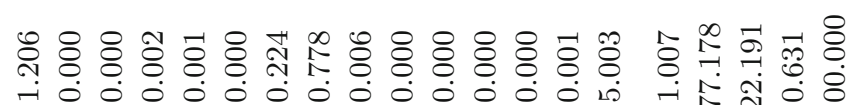

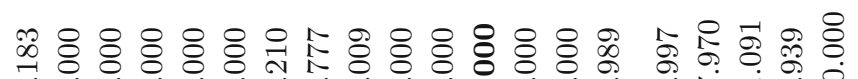

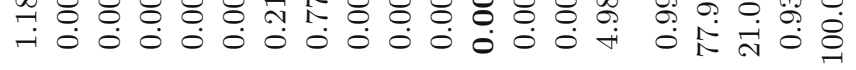
虽 \& \& \& \&

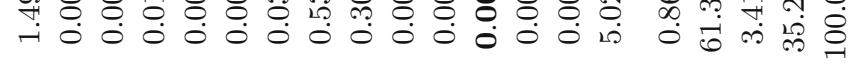

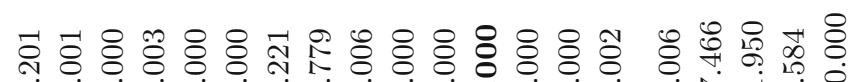

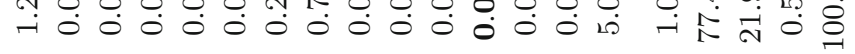

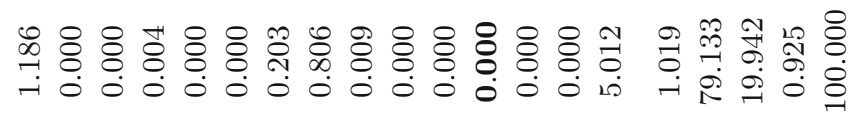

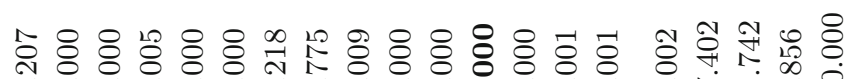

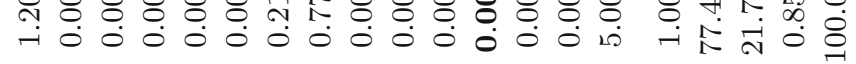
눙 \& \&

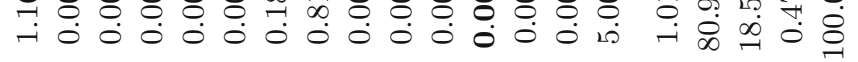

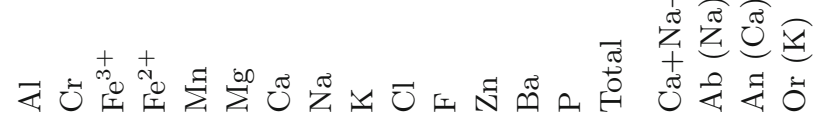

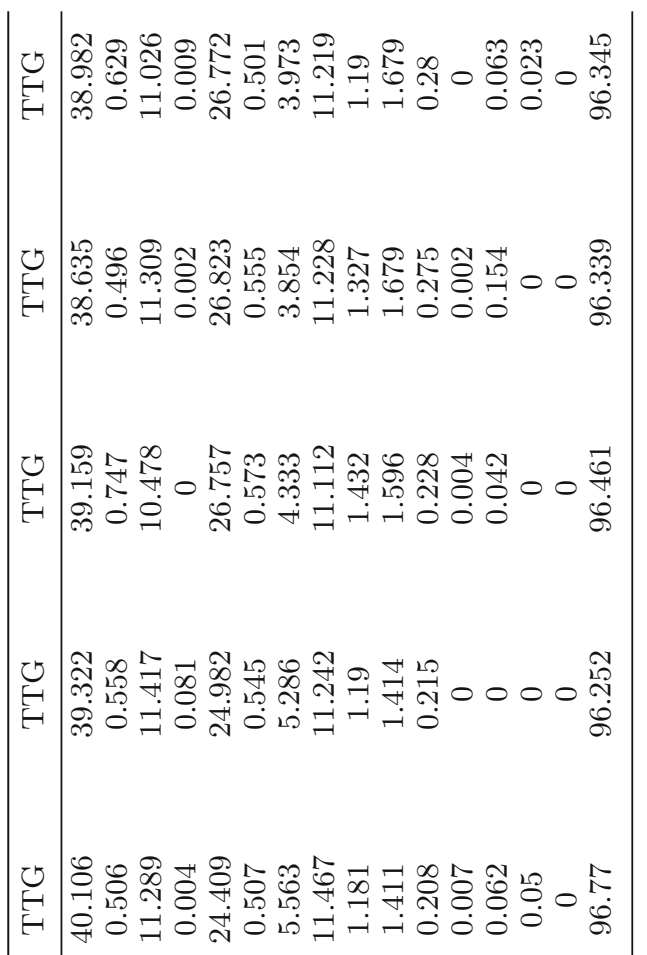

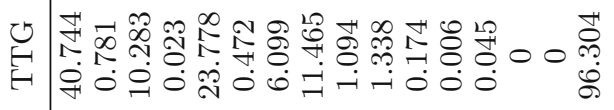

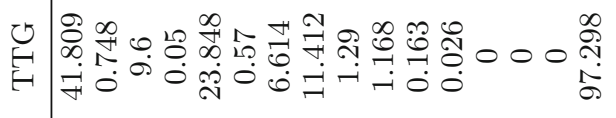

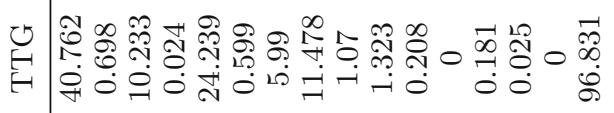

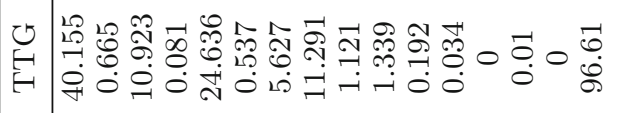

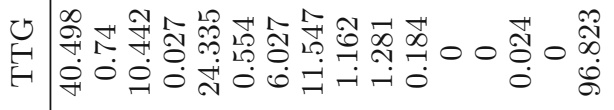

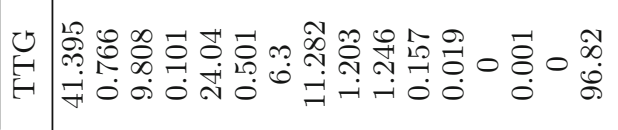

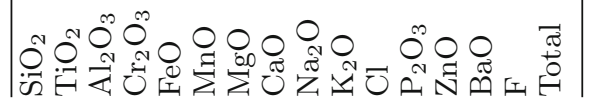




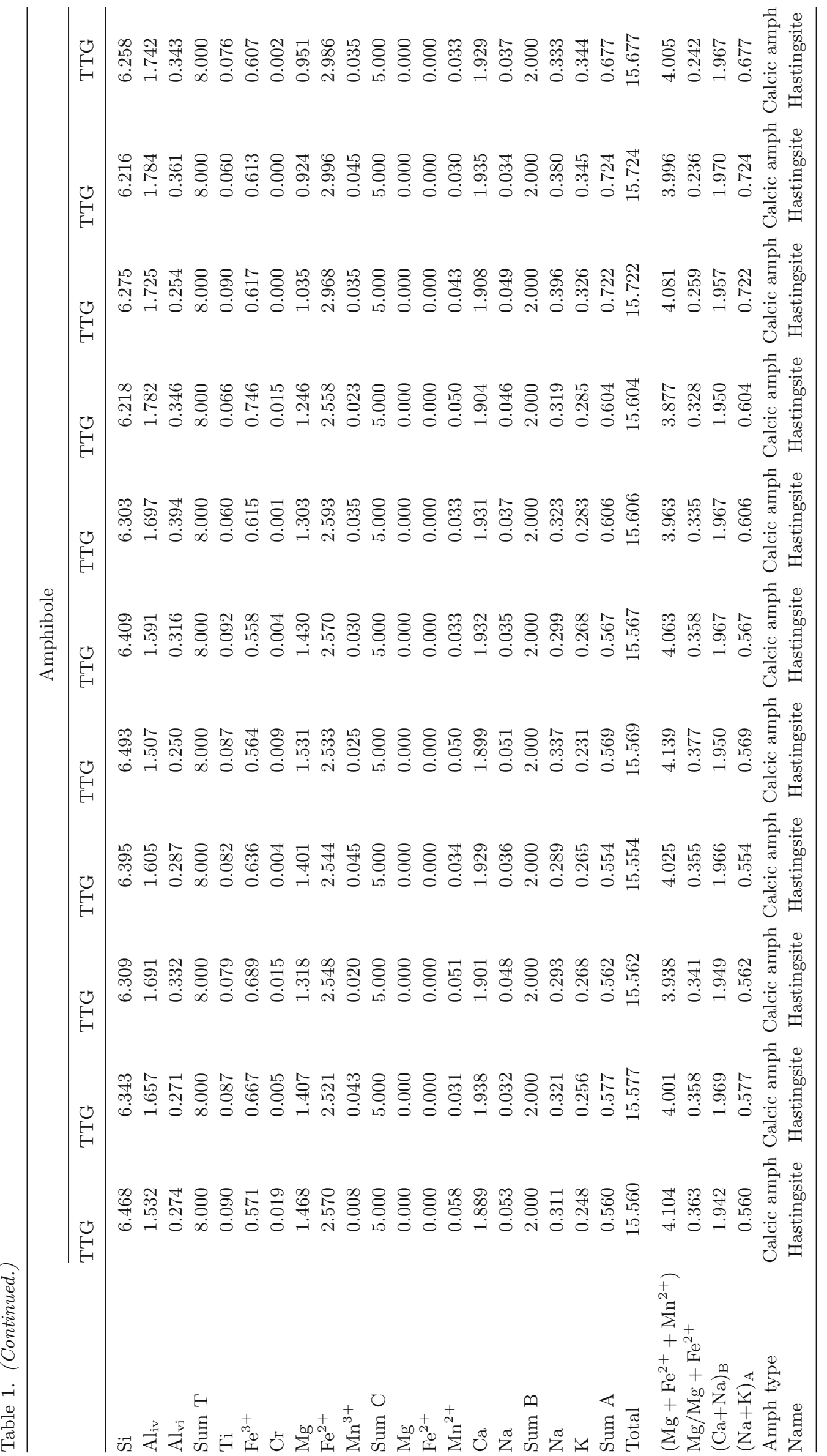




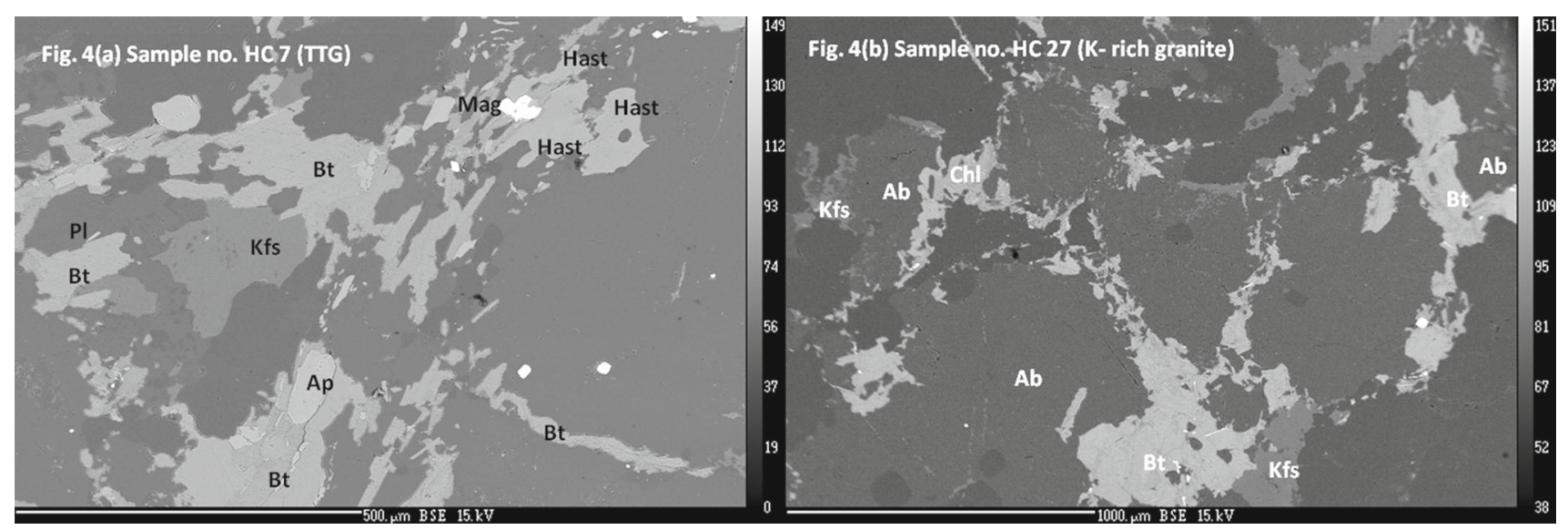

Figure 4. Back-scattered electron images of a representative sample of (a) TTG and (b) K-rich granite showing the characteristic mineral assemblage. Abbreviations are Ab: albite, Chl: chlorite, Ap: apatite, Kfs: potash feldspar, Qtz: quartz, Fsp: feldspar, Hast: hastingsite, and Pl: plagioclase.

(a)

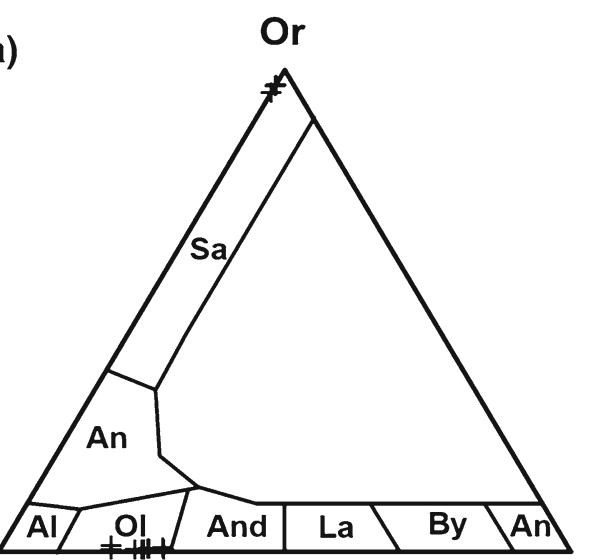

$\mathrm{Ab}$ (b)

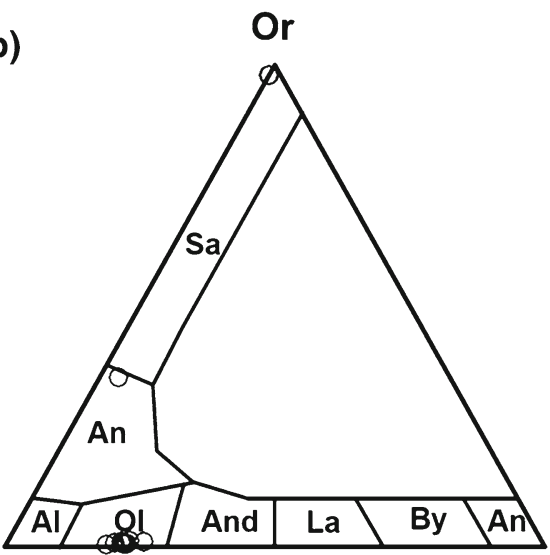

An Ab

An

Figure 5. Triangular plots showing the composition of the feldspars of (a) TTGs and (b) K-rich granites of the Bundelkhand craton after Deer et al. (1992).

granites of the Bundelkhand craton are presented in table 3.

\subsection{TTGs}

The samples of this group contain $\mathrm{SiO}_{2}$ from 64.17 to $74.52 \mathrm{wt} \%$, whereas the total alkalis $\left(\mathrm{Na}_{2} \mathrm{O}+\mathrm{K}_{2} \mathrm{O}\right)$ vary from 5.61 to 7.76 wt\% with $\mathrm{Na}_{2} \mathrm{O} / \mathrm{K}_{2} \mathrm{O}$ ratios from 1.28 to 3.89. These compositions exhibit variable contents of $\mathrm{MgO}$ (0.55 to $1.29 \mathrm{wt} \%$ ) and $\mathrm{Fe}_{2} \mathrm{O}_{3}$ (2.27 to 6.22 and their $\mathrm{Mg} \#$ calculated as $\left[100 \mathrm{Mg}^{2+} /\left(\mathrm{Mg}^{2+}+\mathrm{Fe}^{2+}\right.\right.$ total $), \mathrm{Fe}=$ $0.8998 \mathrm{Fe}^{\mathrm{T}}$ ] vary from 30 to 47 suggesting slightly primitive to evolved composition. $\mathrm{Al}_{2} \mathrm{O}_{3}$ contents of the rocks are 13.49-17.04 wt\%. In the $\mathrm{Ab}-$ Or-An diagram, all the samples are plotted in the tonalite, trondhjemite and granodiorite field (figure 8). The samples were also plotted on the $\mathrm{CaO}-\mathrm{K}_{2} \mathrm{O}-\mathrm{Na}_{2} \mathrm{O}$ diagram of Moyen et al. $(2003 \mathrm{a}, \mathrm{b})$, which is used to distinguish various types of Archaean granites (figure 9), in which samples plot in the TTG and enriched TTG field with a single outlier. These rocks have a calc alkaline affinity and show weakly peraluminous character with $\mathrm{A} / \mathrm{CNK}$ ratios ranging from 1.00 to 1.11 (figure $10 \mathrm{a}, \mathrm{b}$ ). The rocks have Sr contents 175-666 ppm and Y contents 5-42 ppm.

On the primitive mantle normalized (Sun and McDonough 1989) trace element spidergram (figure 11a), the rocks show elevated concentrations of $\mathrm{Nd}, \mathrm{Ba}, \mathrm{Th}, \mathrm{Pb}$ and $\mathrm{Rb}$ and depletions in $\mathrm{Nb}$, $\mathrm{Ti}, \mathrm{P}, \mathrm{Ba}$ with $\mathrm{Sr} / \mathrm{Y}$ ratio of 4.9-98.7. On the chondrite normalized REE patterns, the Bundelk- 
(a)

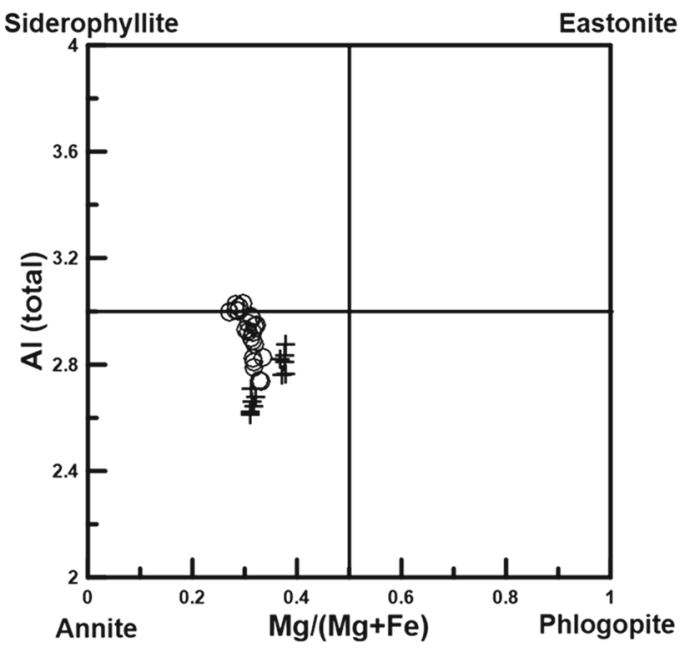

(b)

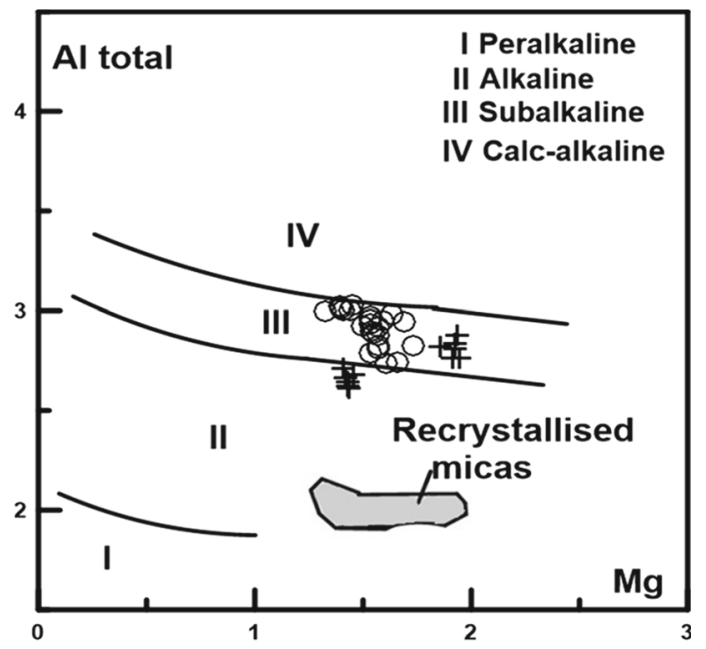

Figure 6. (a) Classification of biotites observed in the TTGs and K-rich granites of the Bundelkhand craton based on the nomenclature of Speer (1984). (b) Plot of Mg vs. Al total of biotites from the Bundelkhand TTGs and K-rich granites after Abdel-Rahman (1994) showing its alkaline affinity.

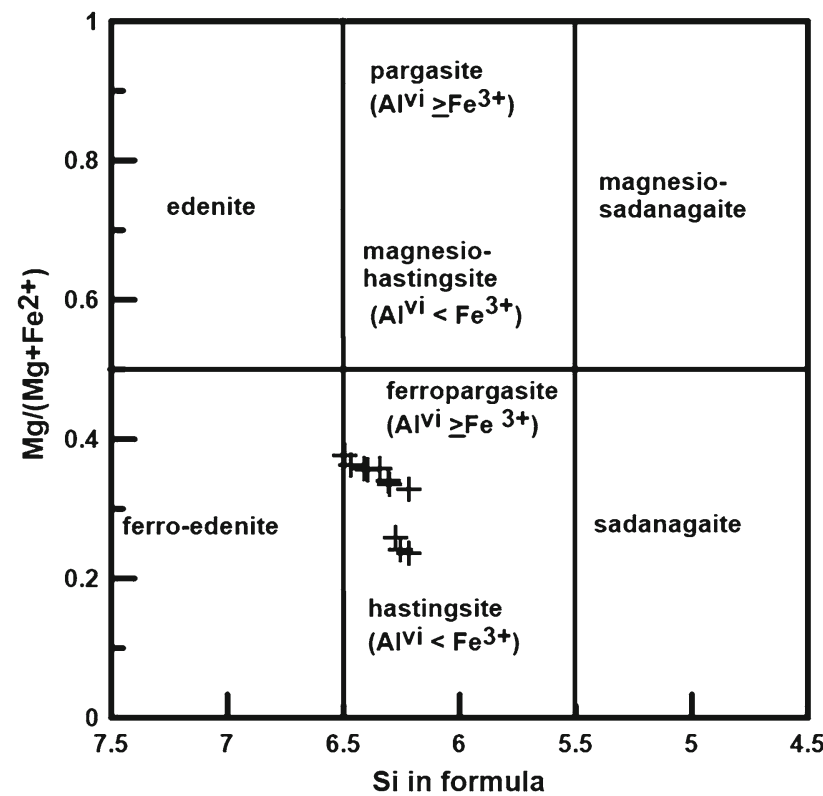

Figure 7. Nomenclature of calcic-amphiboles present exclusively in the TTG gneisses of the Bundelkhand craton. Classification after Leake et al. (1997).

hand craton TTG samples exhibit LREE-enriched and HREE-depleted patterns with moderate $(\mathrm{La} / \mathrm{Yb})_{\mathrm{CN}}=$ where $\mathrm{CN}$ represents chondrite normalized values after McDonough and Sun (1995) (figure 11b). The samples show weakly negative $\mathrm{Eu}$ anomalies $\left(\mathrm{Eu} / \mathrm{Eu}^{*}=1.3-2.7\right)$. The rocks have high La (27-151 ppm) and low Yb (90.67-3.67 $\mathrm{ppm})$ with low $(\mathrm{Gd} / \mathrm{Yb})_{\mathrm{CN}}$ ratios ranging from 2.2 to 4.6 .

\subsection{K-rich granites}

The rocks of this type have $\mathrm{SiO}_{2}$ ranging from 64.72 to $76.73 \mathrm{wt} \%$, low $\mathrm{Na}_{2} \mathrm{O}$ from 2.75 to $3.31 \mathrm{wt} \%$, $\mathrm{Al}_{2} \mathrm{O}_{3}$ from 12.43 to 15.65 wt\%, $\mathrm{Fe}_{2} \mathrm{O}_{3}$ from 2.92 to $4.86 \mathrm{wt} \%$ and $\mathrm{MgO}$ from 0.46 to $1.16 \mathrm{wt} \%$. They show $\mathrm{Na}_{2} \mathrm{O} / \mathrm{K}_{2} \mathrm{O}$ ratios ranging from 0.58 to 0.79 and high $\mathrm{K}_{2} \mathrm{O}$ from 4.21 to $5.44 \mathrm{wt} \%$. The $\mathrm{Mg} \#$ of these rocks range from 24 to 40 . Their total alkalis $\left(\mathrm{Na}_{2} \mathrm{O}+\mathrm{K}_{2} \mathrm{O}\right)$ vary from 7.06 to $8.63 \mathrm{wt} \%$ and are slightly higher than those of their TTG counterparts of this study. In the $\mathrm{CaO}-\mathrm{K}_{2} \mathrm{O}-\mathrm{Na}_{2} \mathrm{O}$ diagram of Moyen et al. (2003a, b), they plot in the biotite granite field due to their higher $\mathrm{K}_{2} \mathrm{O}$ contents than those of studied TTGs (figure 9). On the feldspar normative An-Ab-Or diagram of O'connor (1965) with fields from Barker (1979) the samples plot in the granite field (figure 8). The rocks have Sr contents of 175-648 ppm and $\mathrm{Y}$ concentrations of 27-50 leading to $\mathrm{Sr} / \mathrm{Y}$ ratios of 2-24. All the rocks show a shoshonitic property (figure 12) and weakly peraluminous feature with $\mathrm{A} / \mathrm{CNK}$ ratios ranging from 0.96 to 1.17 (figure 10b).

On the primitive mantle-normalized spidergram (figure 13a), the rocks show negative $\mathrm{Nb}, \mathrm{Ti}, \mathrm{P}$ anomalies, negative to positive $\mathrm{Sr}$ anomalies and positive $\mathrm{K}$ anomalies. These patterns are similar to those of the studied TTGs. All the samples of this group also exhibit a LREE-enriched and HREE-depleted patterns. All the samples show negative Eu anomalies $\left(\mathrm{Eu} / \mathrm{Eu}^{*}=1.97-3.38\right)$ with $(\mathrm{La} / \mathrm{Yb})_{\mathrm{CN}}$ values of 10-27 (figure 13b). 
Table 2. Pressure calculations based on Al-in- Hornblende (using methods of Hammerstrom and Zen 1986; Hollister et al. 1987) and temperature calculations based on the amphibole-plagioclase thermometer of Blundy and Holland (1990) for the TTG suite of Bundelkhand craton.

\begin{tabular}{|c|c|c|c|c|c|c|}
\hline $\begin{array}{l}\text { Sample } \\
\text { no. }\end{array}$ & $\begin{array}{l}\mathrm{Al} \\
(\mathrm{T})\end{array}$ & $\mathrm{Si}$ & $\begin{array}{c}\text { Pressure (Kbar) } \\
\text { (Hammerstrom } \\
\text { and Zen 1986) }\end{array}$ & $\begin{array}{c}\text { Pressure (Kbar) } \\
\text { (Hollister et al. 1987) }\end{array}$ & $\mathrm{X}_{\mathrm{Ab}}$ & $\begin{array}{l}\text { Temp } \\
\left({ }^{\circ} \mathrm{C}\right)\end{array}$ \\
\hline $\mathrm{HC} 7$ & 1.81 & 6.47 & 5.16 & 5.43 & 0.744 & 755 \\
\hline $\mathrm{HC} 7$ & 1.93 & 6.34 & 5.78 & 6.11 & 0.760 & 767 \\
\hline $\mathrm{HC} 7$ & 2.02 & 6.31 & 6.25 & 6.65 & 0.748 & 769 \\
\hline $\mathrm{HC} 7$ & 1.89 & 6.40 & 5.60 & 5.91 & 0.733 & 767 \\
\hline $\mathrm{HC} 7$ & 1.76 & 6.49 & 4.92 & 5.15 & 0.709 & 763 \\
\hline $\mathrm{HC} 7$ & 1.91 & 6.41 & 5.67 & 5.99 & 0.735 & 762 \\
\hline $\mathrm{HC} 7$ & 2.09 & 6.30 & 6.60 & 7.03 & 0.709 & 777 \\
\hline $\mathrm{HC} 9$ & 1.98 & 6.28 & 6.03 & 6.40 & 0.801 & 767 \\
\hline $\mathrm{HC} 9$ & 2.14 & 6.22 & 6.87 & 7.33 & 0.779 & 771 \\
\hline $\mathrm{HC} 9$ & 2.09 & 6.26 & 6.57 & 7.00 & 0.758 & 773 \\
\hline Avg. & & & 5.94 & 6.30 & & 767 \\
\hline
\end{tabular}

\section{Discussion}

\subsection{Petrogenesis}

\subsubsection{TTGs}

The Bundelkhand craton TTGs exhibit similar geochemical characteristics with other known TTG intrusive bodies in Archaean cratons of the world (e.g., Martin and Moyen 2005; Manya et al. 2007). Such characteristics include high concentrations of $\mathrm{Al}_{2} \mathrm{O}_{3}$ (13.49-17.04 wt\%, average $\left.=15.46 \mathrm{wt} \%\right)$, high ratios of $\mathrm{Na}_{2} \mathrm{O} / \mathrm{K}_{2} \mathrm{O}(1.00-54.2)$ and low concentration of heavy REEs with Y contents of 5-42 $\mathrm{ppm}$ and $\mathrm{Yb}=0.3-0.5 \mathrm{ppm}$. The TTG samples cover the entire range of tonalite, trondhjemite and granodiorite in the normalized plot of $\mathrm{Ab}-\mathrm{An}-$ Or with moderate ratios of $\mathrm{Sr} / \mathrm{Y}$ ratios (4.9-98) and $(\mathrm{La} / \mathrm{Yb})_{\mathrm{N}}=15-30$ showing characteristics of TTG and adakites (Condie 2005; Martin and Moyen 2005). The higher La/Yb and $\mathrm{Sr} / \mathrm{Y}$ ratios in the Bundelkhand TTG are a result of low HREE contents in the rocks. Since HREE can strongly partition themselves in garnet and amphibole during mantle melting, the low contents of HREE as well as the higher $\mathrm{La} / \mathrm{Yb}$ and $\mathrm{Sr} / \mathrm{Y}$ ratios in these TTGs can be attributed to the presence of residual garnet and/or hornblende in the source during partial melting (Smithies 2000; Martin and Moyen 2005; Condie 2005).

Debate still persists as to the tectonic setting for the generation of TTG assemblage (Martin 1999; Smithies and Champion 2000; Foley et al. 2002;
Condie 2005; Foley 2008; Moyen 2009), but many workers (e.g., Drummond and Defant 1990; Kay and Kay 1993; Martin 1999; Rapp et al. 1999; Smithies and Champion 2000; Martin and Moyen 2005; Manya et al. 2007; Moyen 2009) have shown that Archaean TTGs and adakites are all interpreted to be the product of partial melting of hydrous basaltic crust in the subduction zones under eclogite facies condition with a characteristic high $\mathrm{Mg} \#$ values and low $\mathrm{Cr}$ and $\mathrm{Ni}$ concentrations due to interaction of the ascending partial melt with the mantle peridotite. Another formation mechanism considered is the partial melting of amphibolite/eclogite at the base of thickened arc crust and partial melting of wet mafic roots of an oceanic plateaus have also been considered, which would produce melts with low $\mathrm{Mg} \#$ values and low $\mathrm{Cr}$ and Ni concentrations (Atherton and Petford 1993; Rapp et al. 1999; Smithies 2000, 2002; Condie 2005; Huang et al. 2014). The Bundelkhand TTG samples of this study have high $\mathrm{SiO}_{2}$ concentrations, low $\mathrm{Mg} \#$ values and low $\mathrm{Cr}$ and Ni concentrations, implying that the trondhjemite samples are probably derived from a hydrous thickened, basaltic lower crust.

When the Bundelkhand TTG rock data are plotted on the major oxide ratios of experimental melts obtained from the partial melting of common crustal rocks such as amphibolites, tonalitic gneisses, metagreywackes and metapelites under variable melting conditions (e.g., Patiño-Douce 1996, 1999), it plots in the field of amphibolites (figure 14a, b). The plotting of the Bundelkhand 


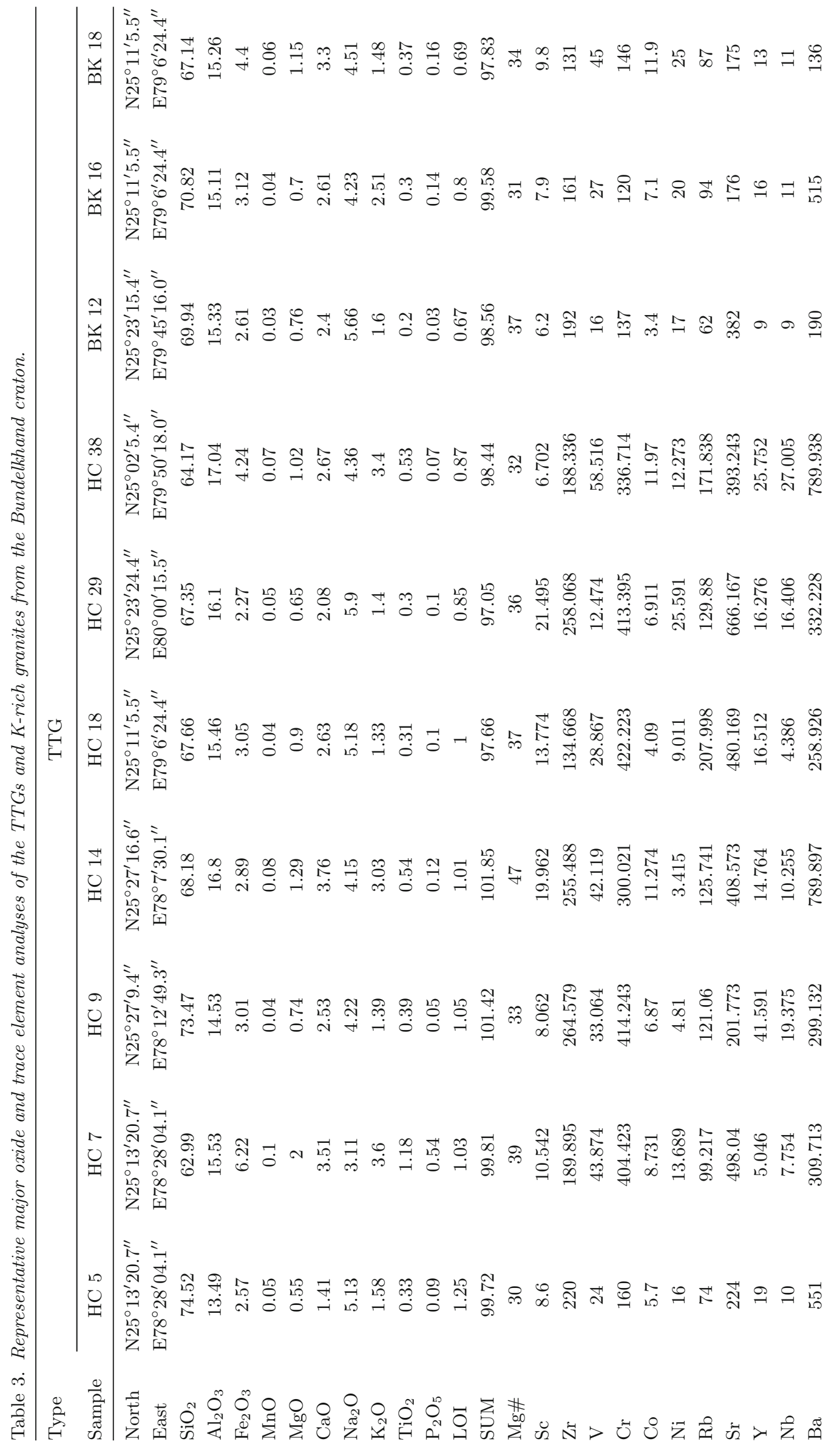




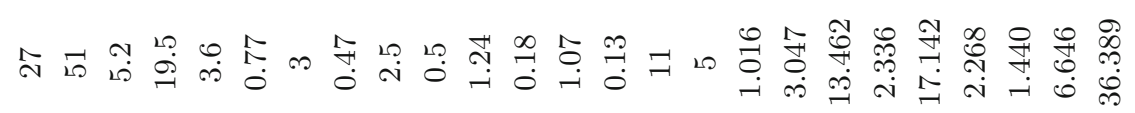

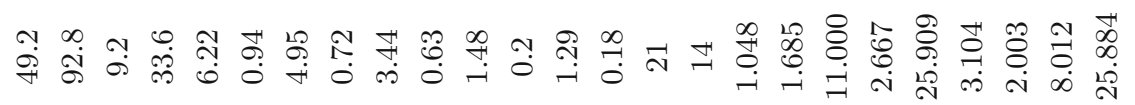
次

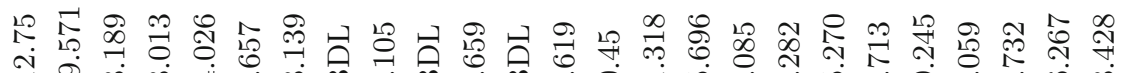

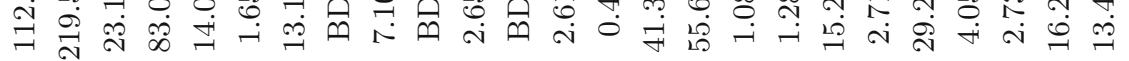

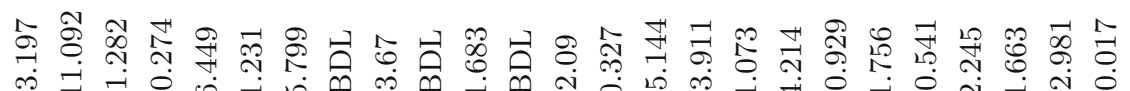

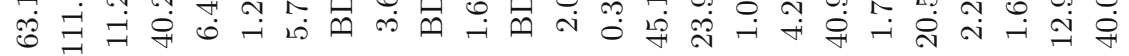

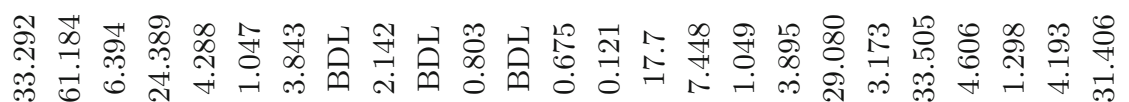

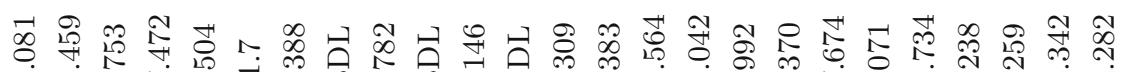
宛

苍侌

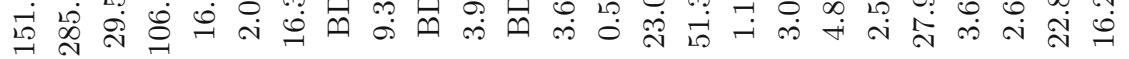

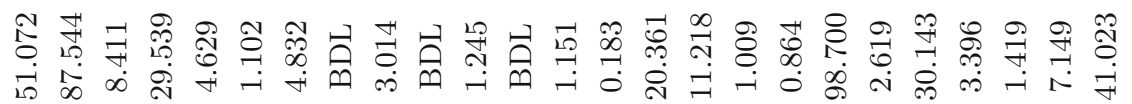

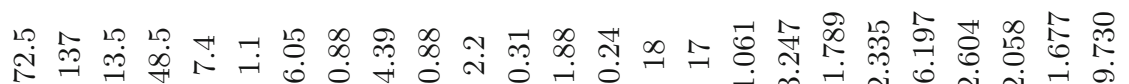

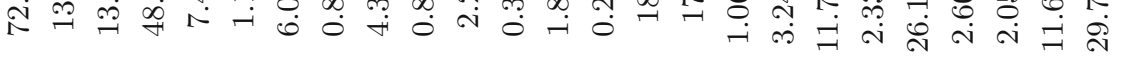

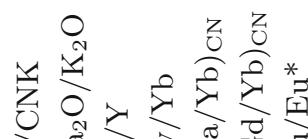

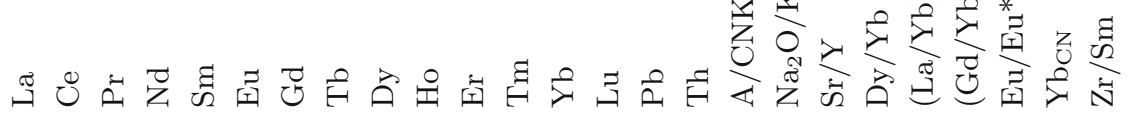




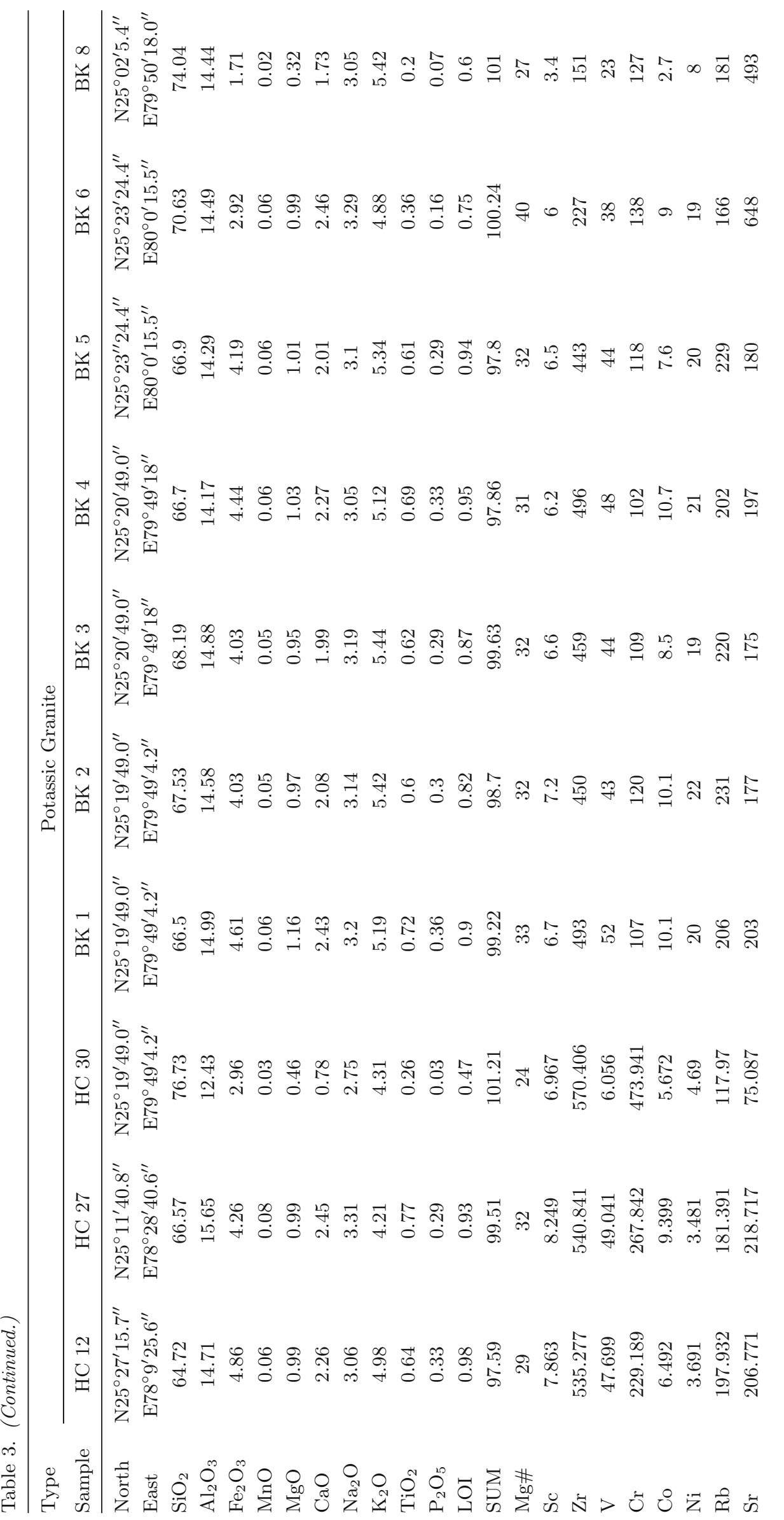




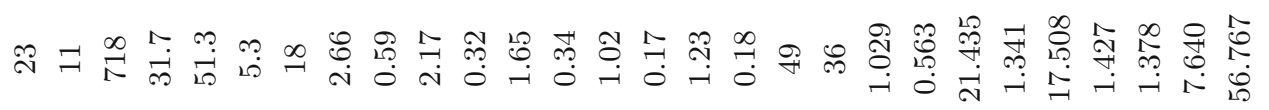

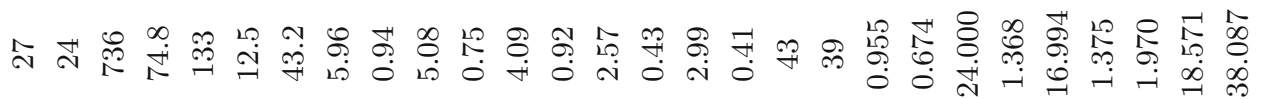

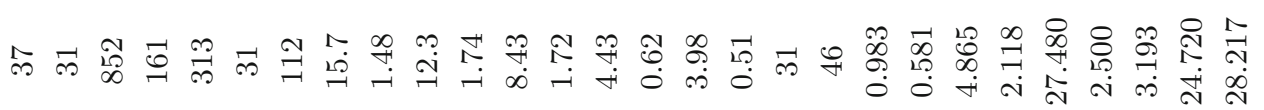

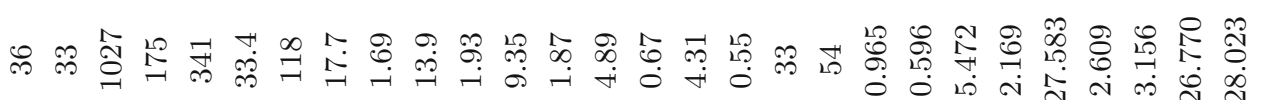

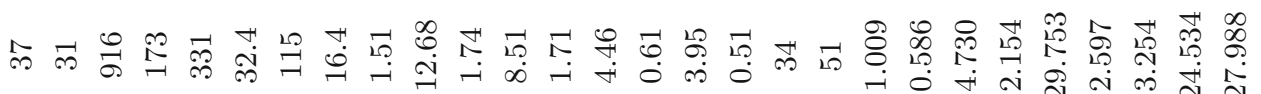

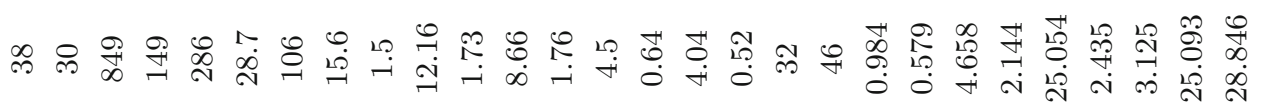

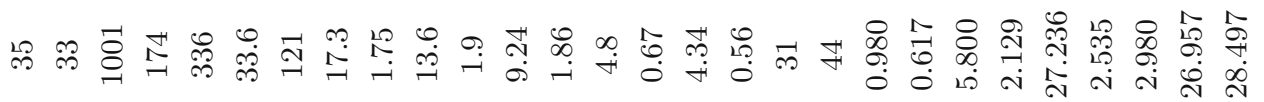

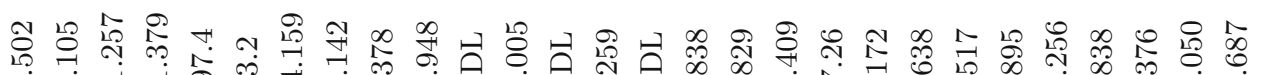

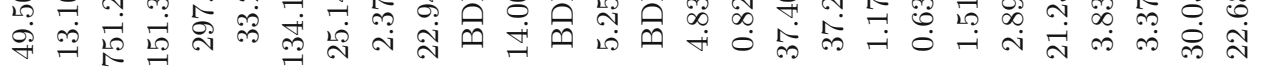

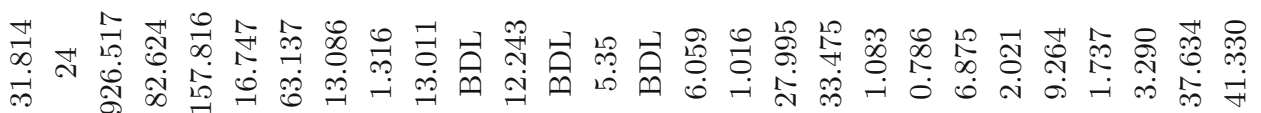

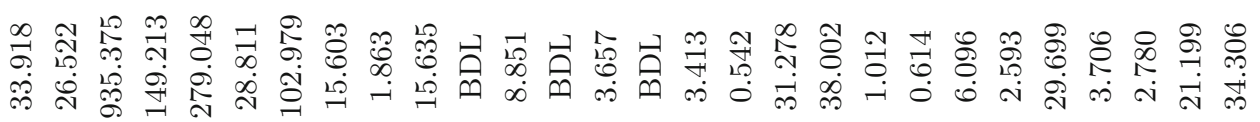

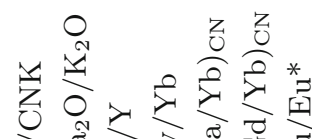

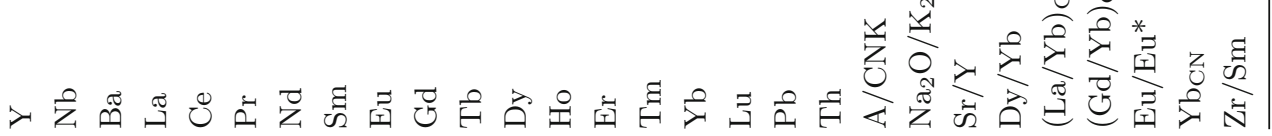




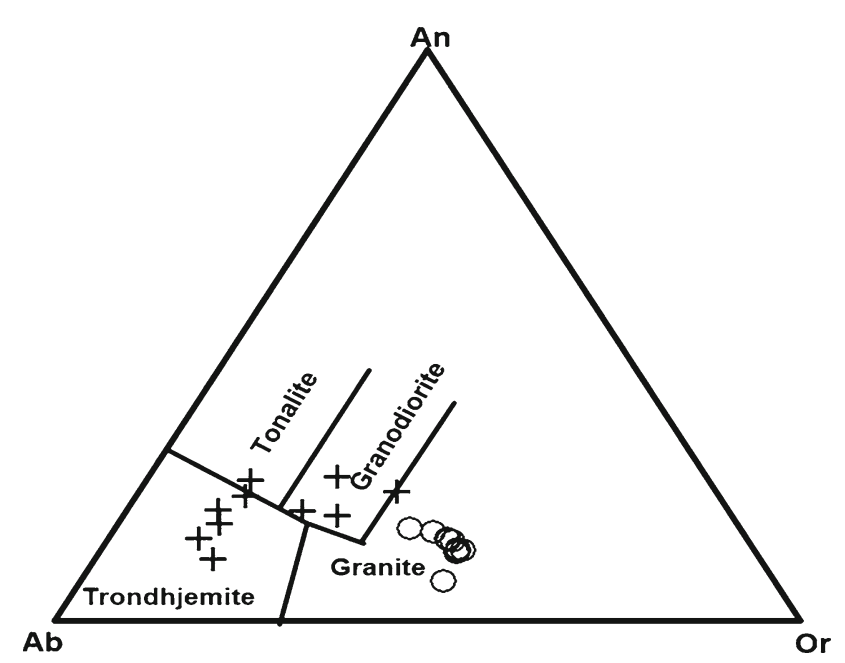

Figure 8. Classification of TTGs and K-rich granites from the Bundelkhand craton on feldspar normative An-Ab-Or diagram of O'connor (1965) with fields from Barker (1979).

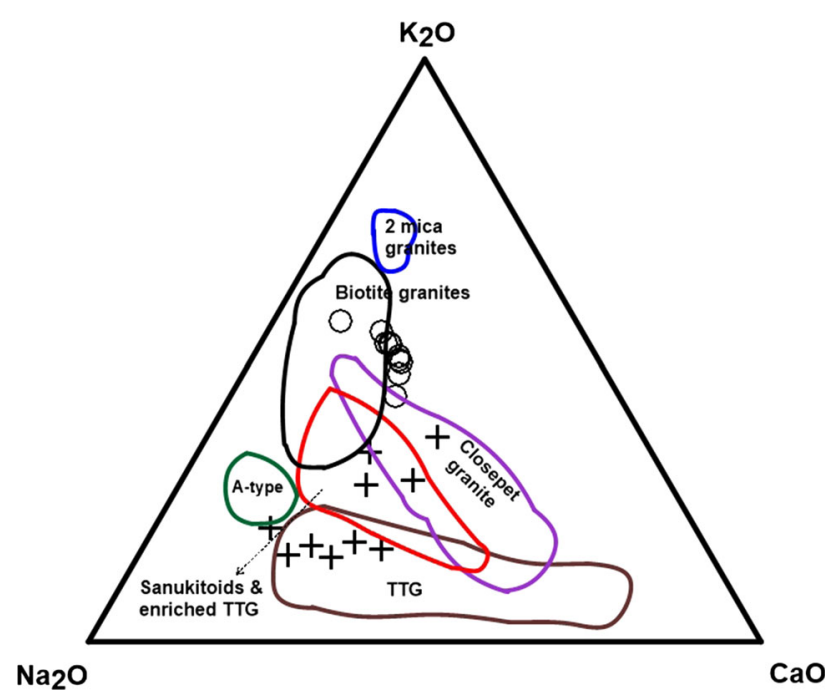

Figure 9. Classification of TTGs and K-rich granites from the Bundelkhand craton based on $\mathrm{CaO}-\mathrm{K}_{2} \mathrm{O}-\mathrm{Na}_{2} \mathrm{O}$ diagram of Moyen et al. (2003a, b).

TTG in the amphibolites field further supports the earlier inference that they result from partial melting of the basaltic crust. This interpretation is consistent with experimental studies which showed that melting of metabasalts and amphibolites at various $\mathrm{p}_{\mathrm{H} 2 \mathrm{O}}$ conditions and depths where garnet and amphibole are stable phases would produce the TTG-like melts (e.g., Rapp et al. 1991; Wolf and Wyllie 1994).

Presence of negative Eu anomaly implies plagioclase removal by fractional crystallization or as a residual phase during partial melting. The observed HREE depletion for these samples indicates the potential residual phases of garnet and/or amphiboles during partial melting or garnet and/or amphibole fractionation during its ascent through mantle. Macpherson et al. (2006) have suggested that partial melting with garnet in the residue will effectively increase the $\mathrm{Sr} / \mathrm{Y}, \mathrm{La} / \mathrm{Yb}, \mathrm{Gd} / \mathrm{Yb}$ and $\mathrm{Dy} / \mathrm{Yb}$ ratios, while if amphibole is the residual phase the melts will have a low $\mathrm{Nb} / \mathrm{Ta}, \mathrm{Gd} / \mathrm{Yb}$ and $\mathrm{Dy} / \mathrm{Yb}$ ratios. In the case of the Bundelkhand TTG rocks, they show moderate $(\mathrm{La} / \mathrm{Yb})_{\mathrm{CN}}$ values $(15$ $30), \mathrm{Sr} / \mathrm{Y}$ ratios $(4.9$ to 98.7$)$ and low $(\mathrm{Gd} / \mathrm{Yb})_{\mathrm{CN}}$ ratios (2.2-4.6) and no correlation could be established between $\mathrm{Sr} / \mathrm{Y}$ ratios and $(\mathrm{La} / \mathrm{Yb})_{\mathrm{N}}$ values. This implies that the parental magma of these samples was probably derived from partial melting of a source with both amphibole and garnet in the residue. Based on our inferences it is suggested that Bundelkhand TTG was probably derived by partial melting of hydrous basaltic crust in the late Archaean collisional zone at pressures and depths where garnet and amphibole were stable phases.

\subsubsection{K-rich granites}

The potassic granite samples of this study have high $\mathrm{SiO}_{2}, \mathrm{~K}_{2} \mathrm{O}$ and low $\mathrm{Na}_{2} \mathrm{O}, \mathrm{MgO}, \mathrm{CaO}$ contents. They also have LREE-enriched and HREEdepleted patterns (relatively flat) to those of the TTG samples. These REE patterns and high $(\mathrm{La} / \mathrm{Yb})_{\mathrm{CN}}$ values $(25.4-202), \mathrm{Sr} / \mathrm{Y}$ ratios $(12.8$ $119)$ and low $(\mathrm{Gd} / \mathrm{Yb})_{\mathrm{CN}}(2.70-11.1)$ ratios and the lack of $\mathrm{Sr} / \mathrm{Y}$ ratios correlation with $(\mathrm{La} / \mathrm{Yb})_{\mathrm{CN}}$ values indicate the parental magma of these samples perhaps were derived from partial melting of a source with garnet and amphibole in the residue. Negative Eu anomalies observed in these samples possibly suggest plagioclase existing in the residue and/or plagioclase fractionation during magma ascent. The absence of evidence of any preexisting high $\mathrm{Sr} / \mathrm{Y}$ and $\mathrm{La} / \mathrm{Yb}$ sources in the Bundelkhand area suggests that these K-rich granites also probably generated from partial melting of hydrous mafic rocks with garnet and amphibole in the residue (e.g., Smithies 2000; Martin and Moyen 2005; Condie 2005). The K-rich granites are generally considered to have generated by partial melting of subducted slab with assimilation/interaction of mantle wedge peridotite or the product of reworking and partial melting of lower crustal materials (Moyen et al. 2003a, b; Jayananda et al. 2006; Moyen 2011), which is supported by experimental studies (Skjerlie and Johnston 1993; Wang et al. 2005; Watkins et al. 2007). Most of the potassic granite samples in this study show high 
(a)

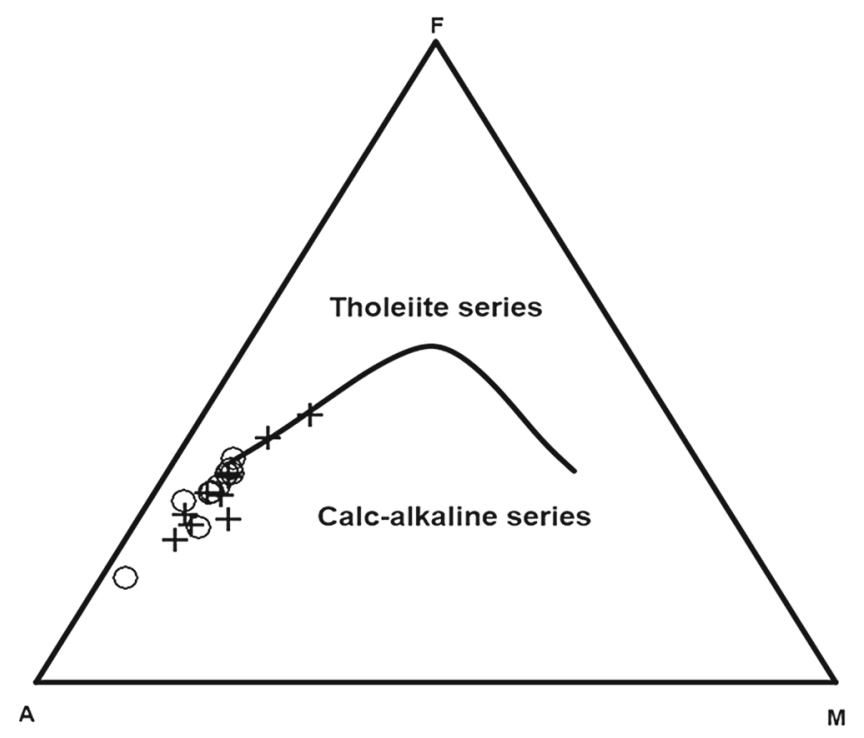

(b)

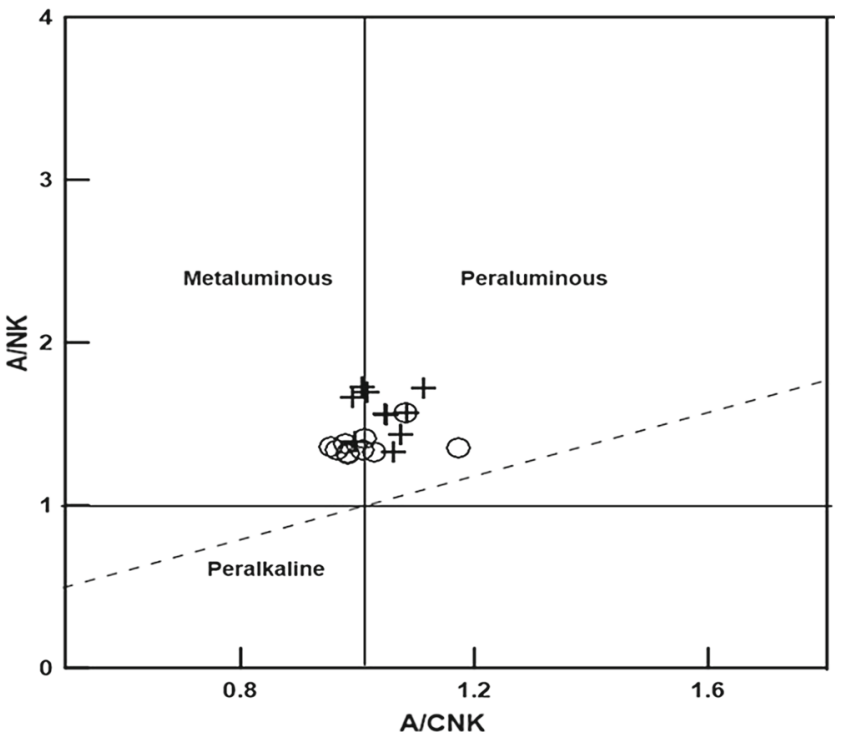

Figure 10. (a) Calc-alkaline natures of TTGs and K-rich granites from Bundelkhand craton can be clearly observed in the A-F-M plot (trends from Irvine and Baragar 1971). (b) A/NK vs. A/CNK diagram showing the peraluminous nature of the TTGs and K-rich granites from the Bundelkhand craton (after Maniar and Piccoli 1989).

(a)

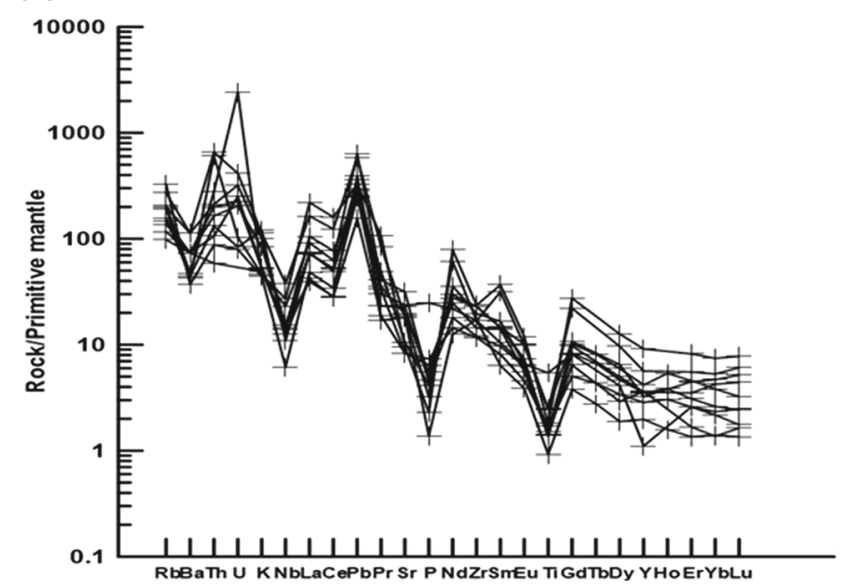

(b)

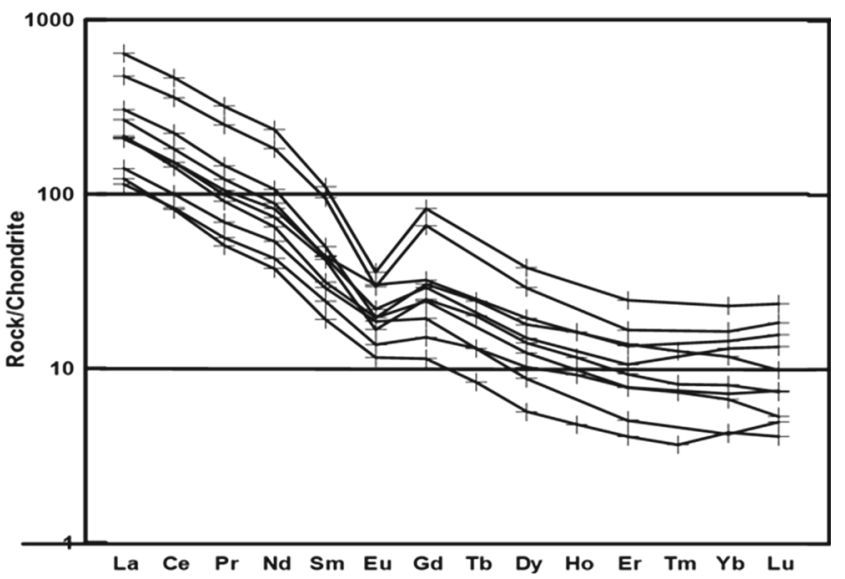

Figure 11. (a) Chondrite normalized rare earth element plots and (b) primitive mantle normalized multi-element patterns for the representative TTG samples from the Bundelkhand craton. Normalizing values of primitive mantle are after Sun and McDonough (1989) and those of Chondrite are after McDonough and Sun (1995).

$\mathrm{SiO}_{2}, \mathrm{~K}_{2} \mathrm{O}$ and low $\mathrm{MgO}$, ruling out of the basaltic oceanic crustal source (Smithies 2000). Therefore, it is suggested that most of the K-rich granites in this area were derived from partial melting of lower crustal sources.

The Bundelkhand K-rich granites differ from their TTG counterparts in having elevated concentrations of incompatible elements like $\mathrm{K}, \mathrm{Zr}$, Th and REE. They, however, share some geochemical features including the negative Eu anomalies in chondrite-normalized diagrams, the $\mathrm{Nb}-\mathrm{Ti}$ anomalies in multi-element spidergrams, plotting mostly in the volcanic arc granite field with a few straddling the volcanic arc granite field to postcollisional granite field (figure 15). The higher concentrations of the incompatible elements are consistent with their derivation from evolved crustal sources. This is particularly true as the mafic rocks have insufficient $\mathrm{K}_{2} \mathrm{O}$ to yield potassic $\mathrm{SiO}_{2}$-rich granitic magmas as those of the Bundelkhand. When plotted on the experimental melts involving major element oxide ratios (figure 14a, b), the Bundelkhand K-granites plot in the amphibolites field. The most plausible explanation for the 
shared geochemical characteristics between the Bundelkhand TTG and K-granites (except for the high concentration of incompatible elements in the later) is that the K-granites were derived by partial melting of the TTG (and greenstones). Thus, the subduction zone signature shown by the Kgranites (i.e., the $\mathrm{Nb}, \mathrm{Ti}$ anomalies and plotting in the volcanic arc granite field) could be attributed

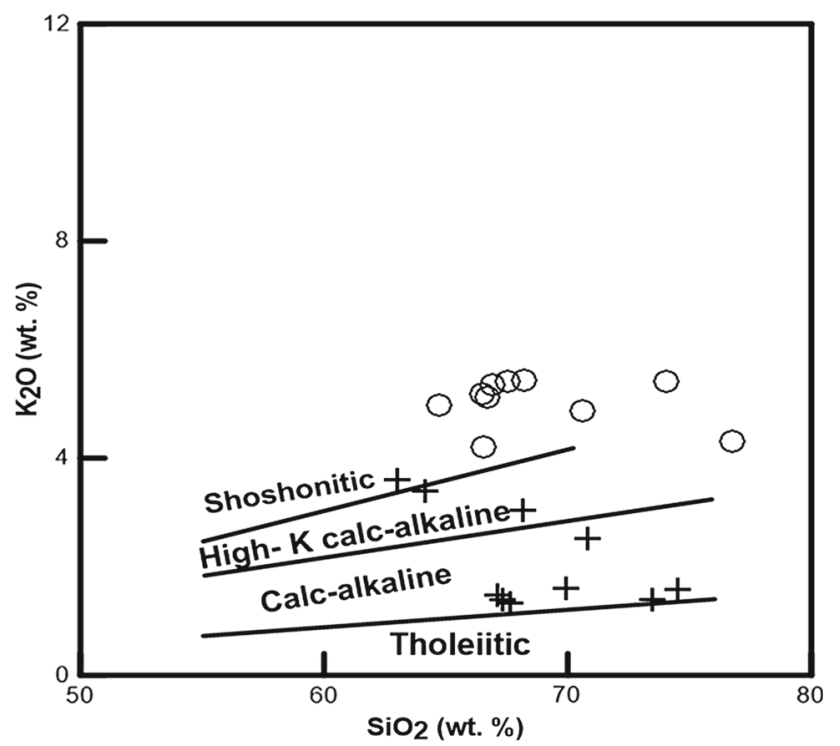

Figure 12. $\mathrm{K}_{2} \mathrm{O}$ vs. $\mathrm{SiO}_{2}$ plot (after Peccerillo and Taylor 1976) indicates shoshonitic to high K calc-alkaline nature of the potassic granites of the Bundelkhand craton. to characteristics of the source rocks. Several experimental studies have shown that partial melting of anhydrous metatonalites within the middle or lower crust could produce granitic melts (Rutter and Wyllie 1988; Skjerlie and Johnston 1993; Patiño-Douce 2005; Watkins et al. 2007). Additionally, Watkins et al. (2007) emphasized that melting of TTGs with high $\mathrm{K}_{2} \mathrm{O} / \mathrm{Na}_{2} \mathrm{O}(>0.3)$ could generate K-rich granites.

The temperatures of the K-rich granites calculated using this $\mathrm{Zr}$ saturation thermometer (Watson and Harrison 1983; Miller et al. 2003) yield an average temperature of the granitic melts of the rock samples as $865^{\circ} \mathrm{C}$, which is inferred to be the crystallization temperature of magma (table 4).

\subsection{Episodic crustal growth in Bundelkhand craton}

The major lithological units reported so far from the Bundelkhand craton are as follows:

- The metamorphosed supracrustal rocks (basaltic to basaltic andesitic pillow, massive lava, serpentinised ultramafic rock, volcaniclastic sediment, tuff) in association with BIF, schist, amphibolites, calc-silicate and interbedded quartzite (Malviya et al. 2004, 2006). Malviya et al. (2006) have reported that in Spar river section TTG gneisses are seen-cross cutting these (a)

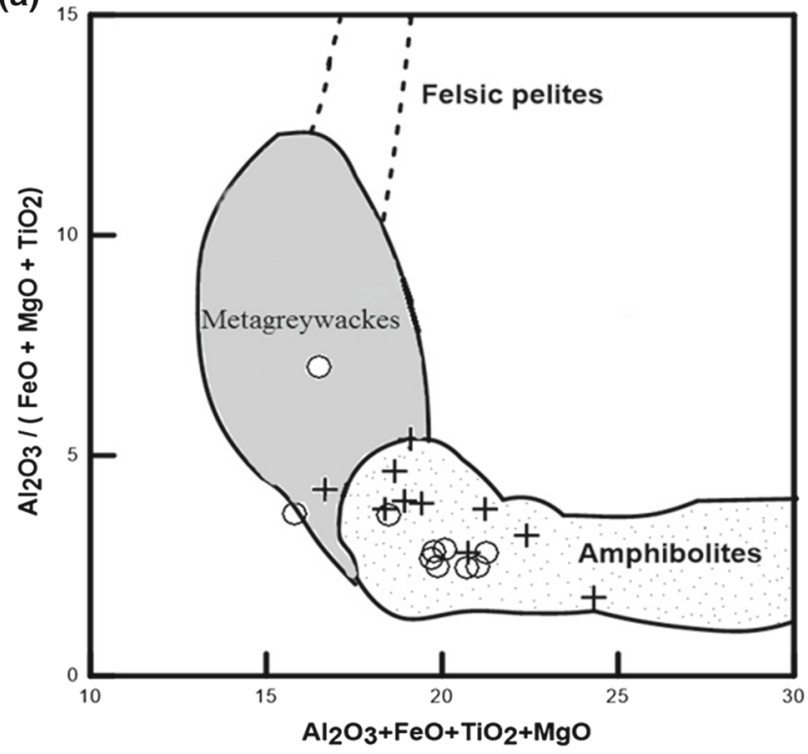

(b)

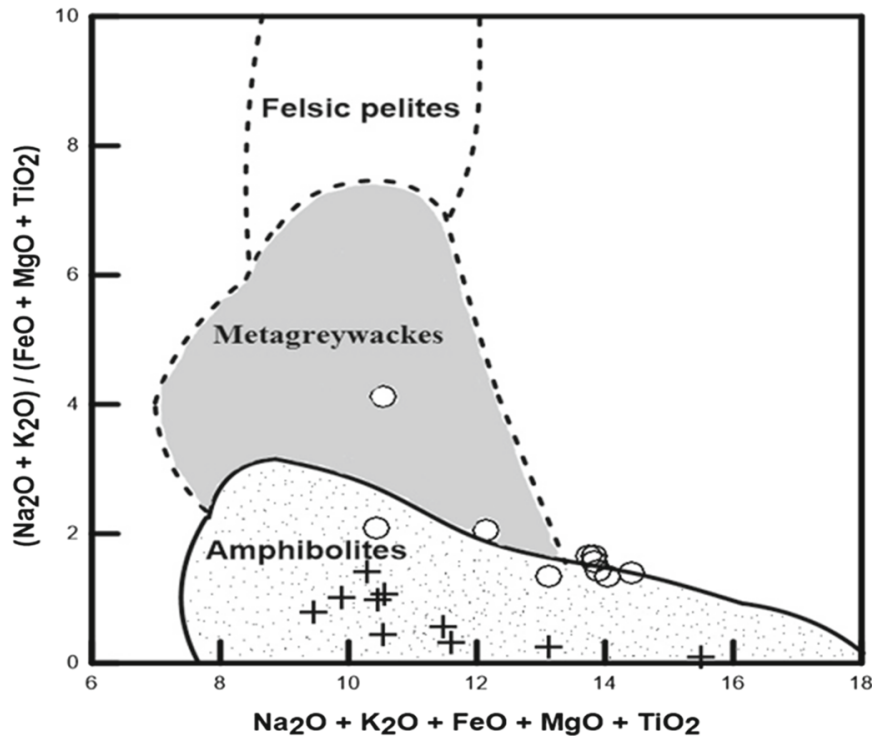

Figure 13. The Bundelkhand craton TTGs and K-rich granites plotted on the (a) $\mathrm{Al}_{2} \mathrm{O}_{3} /\left(\mathrm{FeO}+\mathrm{MgO}+\mathrm{TiO}_{2}\right)$ vs. $\mathrm{Al}_{2} \mathrm{O}_{3}+$ $\mathrm{FeO}+\mathrm{MgO}+\mathrm{TiO}_{2}$ and $(\mathbf{b})\left(\mathrm{Na}_{2} \mathrm{O}+\mathrm{K}_{2} \mathrm{O}\right) /\left(\mathrm{FeO}+\mathrm{MgO}+\mathrm{TiO}_{2}\right)$ vs. $\left(\mathrm{Na}_{2} \mathrm{O}+\mathrm{K}_{2} \mathrm{O}+\mathrm{FeO}+\mathrm{MgO}+\mathrm{TiO}\right)_{2}$ diagrams. Outlined fields show compositions of partial melts obtained in experimental studies by dehydration melting of felsic pelites, metagreywackes, amphibolites-metabasalts and metatonalite sources (Wolf and Wyllie 1994; Patiño-Douce 1996, 1999; Thompson 1996, and references therein). 
(a)

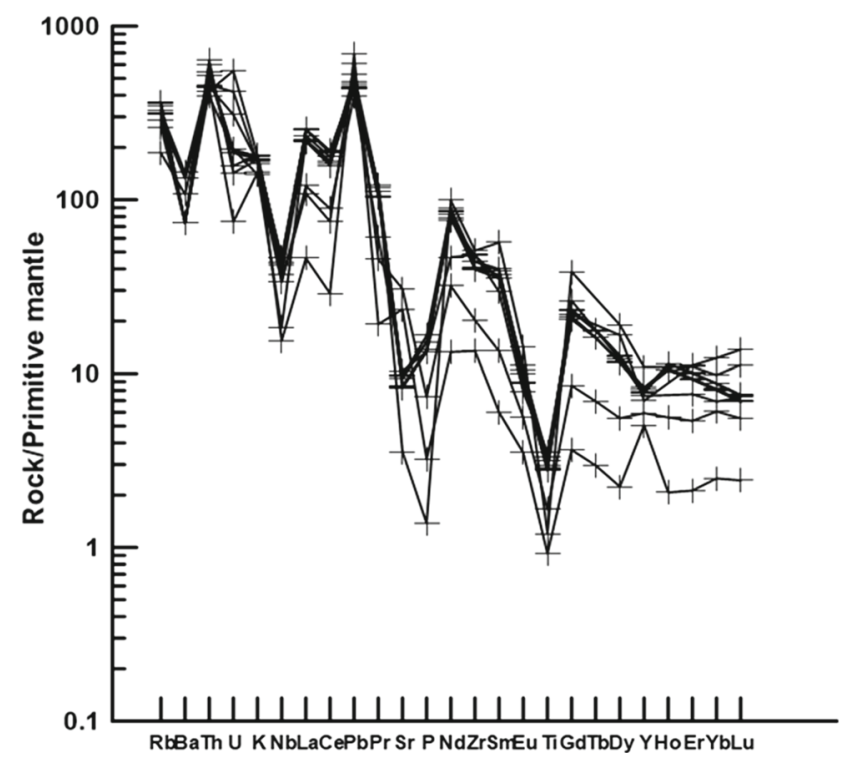

(b)

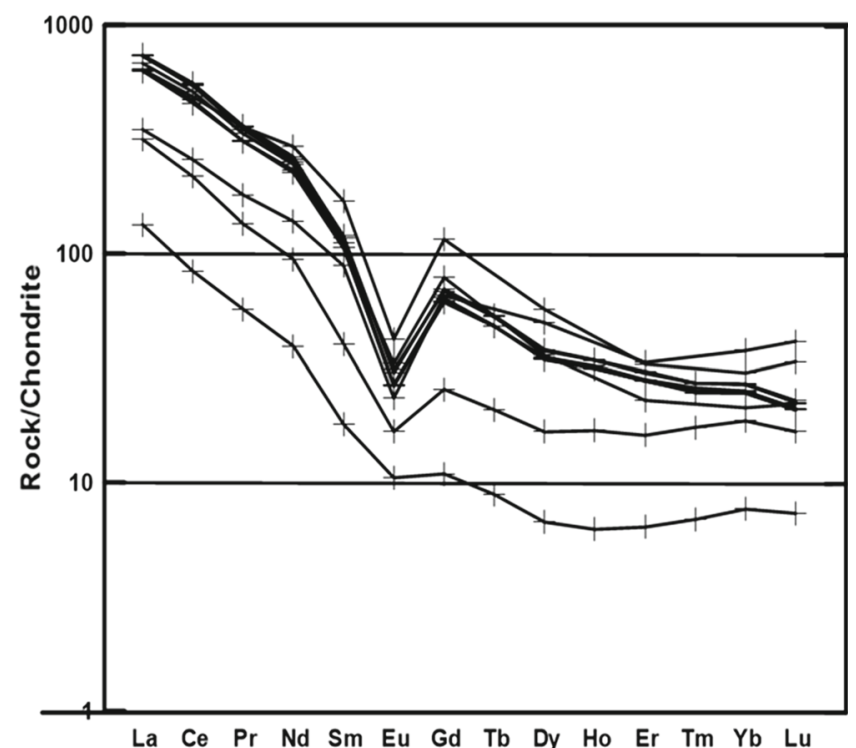

Figure 14. (a) Primitive mantle normalized multi-element patterns and (b) chondrite normalized rare earth element plots for the representative K-rich granite samples of the Bundelkhand craton. Normalizing values of primitive mantle are after Sun and McDonough (1989) and those of chondrite are after McDonough and Sun (1995).

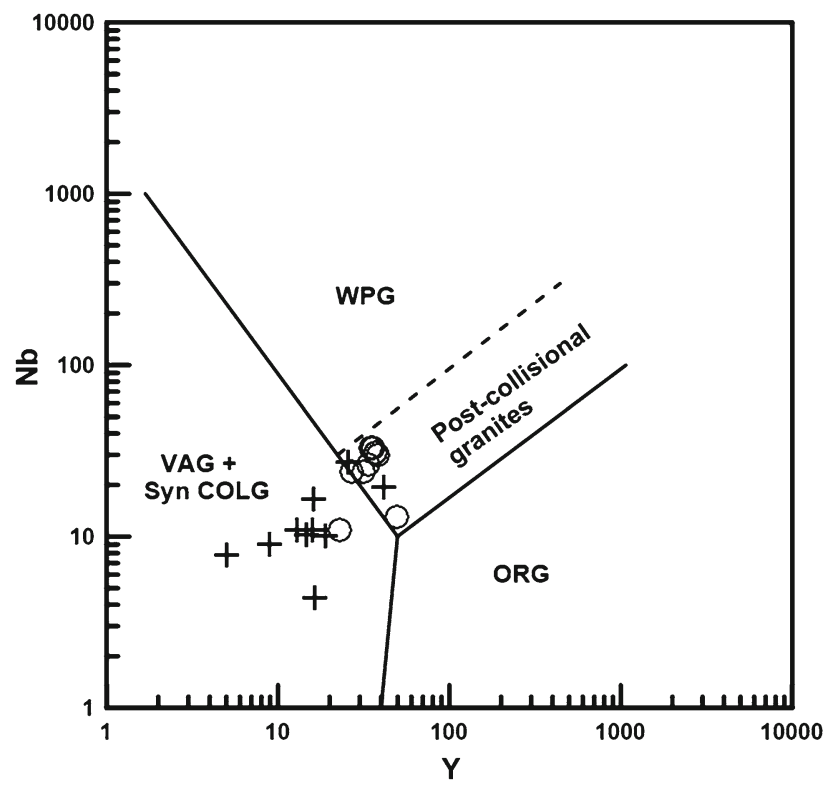

Figure 15. Nb vs. Y tectonic discrimination diagram for the K-rich granites of the Bundelkhand craton (after Pearce et al. 1984). Field labels: Volcanic Arc Granite (VAC), Within Plate Granite (WPG), Ocean Ridge Granite (ORG), and Syn-Collisional Granite (Syn-COLG).

rocks, hence based on the observed structural relation suggested that these may be the oldest unit.

- TTG suite ranging in age from 3.59 to $2.6 \mathrm{Ga}$, wherein most reported ages are in the range of 3.5-3.0 Ga (Sarkar et al. 1984; Mondal et al. 2002; Kaur et al. 2014, 2016; Saha et al. 2016; Joshi et al. 2016) with a recent report of TTG age by Verma et al. (2016) of 2.6 Ga. It is worth mentioning that both work of Saha et al. (2016) and Verma et al. (2016) are bereft of any bulk rock geochemical data for TTG classification. Sharma (1998) suggested that the granitic gneiss with TTG affinity $(3.3 \mathrm{Ga})$ intrudes the mafic and ultramafic and metasedimentary supracrustal rocks, hence predates the TTG gneisses of the Bundelkhand craton.

- A metamorphic episode from white mica schist is reported by Saha et al. (2011) of 2.7-2.4 Ga.

- The granites/granitoids/granitic gneisses/granodioritic gneisses ranging in age from 2.7 to 1.9 Ga (Mondal et al. 2002; Mohan et al. 2012; Kaur et al. 2016; Joshi et al. 2016 and references therein).

- The quartz reefs/giant veins of 2.0-1.8 Ga (Pati et al. 1997; Bhattacharya and Singh 2013).

- The dyke swarms (mafic to ultramafic) -2.0 to 0.9 Ga (Sarkar et al. 1997; Sharma and Rahman 2000; Rao et al. 2005; Pradhan et al. 2012; Radhakrishna et al. 2013).

- Gwalior basin [2.1-2.0 Ga: Rao et al. 2005; 1.83 Ga: Ramakrishnan and Vaidyanadhan 2010; 1.85 Ga: Deb et al. (2002); 2.0-1.79 Ga: Absar et al. (2009); $1.83 \mathrm{Ga}$ : Crawford (1970)] and the Bijawar basin [1.79 Ga and 1.69 Ga: Haldar and Ghosh (2000)] are of Paleoproterozoic age.

More accurate geochronological data obtained as mentioned above in the last decade from the 
Table 4. Cation fractions of 10 major oxides, $\mathrm{Zr}$ concentration, calculated values of $M$ and $T$ in degree celsius using the Zr thermometry of Watson and Harrison (1983) and Miller et al. (2003) for K-rich granites of the Bundelkhand craton.

\begin{tabular}{lrrrrrrrrrr}
\hline Sample no. & HC 12 & HC 27 & HC 30 & BK 1 & BK 2 & BK 3 & BK 4 & BK 5 & BK 6 & BK 8 \\
\hline $\mathrm{SiO}_{2}$ & 64.720 & 66.570 & 76.730 & 66.500 & 67.530 & 68.190 & 66.700 & 66.900 & 70.630 & 74.040 \\
$\mathrm{Al}_{2} \mathrm{O}_{3}$ & 14.710 & 15.650 & 12.430 & 14.990 & 14.580 & 14.880 & 14.170 & 14.290 & 14.490 & 14.440 \\
$\mathrm{Fe}_{2} \mathrm{O}_{3}$ & 4.860 & 4.260 & 2.960 & 4.610 & 4.030 & 4.030 & 4.440 & 4.190 & 2.920 & 1.710 \\
$\mathrm{MnO}$ & 0.060 & 0.080 & 0.030 & 0.060 & 0.050 & 0.050 & 0.060 & 0.060 & 0.060 & 0.020 \\
$\mathrm{MgO}$ & 0.990 & 0.990 & 0.460 & 1.160 & 0.970 & 0.950 & 1.030 & 1.010 & 0.990 & 0.320 \\
$\mathrm{CaO}$ & 2.260 & 2.450 & 0.780 & 2.430 & 2.080 & 1.990 & 2.270 & 2.010 & 2.460 & 1.730 \\
$\mathrm{Na}_{2} \mathrm{O}$ & 3.060 & 3.310 & 2.750 & 3.200 & 3.140 & 3.190 & 3.050 & 3.100 & 3.290 & 3.050 \\
$\mathrm{~K}_{2} \mathrm{O}$ & 4.980 & 4.210 & 4.310 & 5.190 & 5.420 & 5.440 & 5.120 & 5.340 & 4.880 & 5.420 \\
$\mathrm{TiO}_{2}$ & 0.640 & 0.770 & 0.260 & 0.720 & 0.600 & 0.620 & 0.690 & 0.610 & 0.360 & 0.200 \\
$\mathrm{P}_{2} \mathrm{O}_{5}$ & 0.330 & 0.290 & 0.030 & 0.360 & 0.300 & 0.290 & 0.330 & 0.290 & 0.160 & 0.070 \\
$\mathrm{Zr}($ ppm $)$ & 535.277 & 540.841 & 570.406 & 493.000 & 450.000 & 459.000 & 496.000 & 443.000 & 227.000 & 151.000 \\
$\mathrm{M}$ & 1.568 & 1.457 & 1.181 & 1.623 & 1.583 & 1.544 & 1.616 & 1.583 & 1.587 & 1.414 \\
$\left.\mathrm{Temp}^{\circ}{ }^{\circ} \mathrm{C}\right)$ & 887.299 & 898.322 & 929.742 & 874.048 & 868.222 & 873.535 & 875.196 & 866.576 & 802.739 & 779.872 \\
\hline
\end{tabular}

granitoids of Bundelkhand craton of central Indian shield, reveals obvious episodic magmatic activities from the region at 3.59-3.0 Ga, 2.6-2.1 Ga and 2.0-0.9 Ga.

The first episode of magmatic activity (3.5$3.0 \mathrm{Ga}$ ) is recorded in the TTG gneisses and granodioritic gneisses of the Bundelkhand Craton (Sharma and Rahman 1995; Sarkar et al. 1996; Mondal et al. 2002; Saha et al. 2011, 2016; Kumar et al. 2011; Kaur et al. 2014, 2016). This can be further classified into two groups. The first subgroup represented by the granitoids formed at 3.59-3.39 Ga (Kaur et al. 2014, 2016; Joshi et al. 2016; Saha et al. 2016), which are predominantly composed of TTG gneisses and were interpreted as production of partial melting of deep seated mafic crust with abundant garnet and rutile but no plagioclase (Kaur et al. 2016; Saha et al. 2016). The second subgroup (3.2-3.00 Ga) is represented by minor TTG gneisses and granodiorite gneisses (Mondal et al. 1998; Kaur et al. 2014 , 2016) which exhibit high $\mathrm{SiO}_{2}$ and low $\mathrm{MgO}(\mathrm{Mg} \#)$ and were explained as the results of partial melting a more shallow, garnet-free, but plagioclase-rich mafic source (Mondal et al. 2002; Kaur et al. 2016), probably triggered by underplating of basaltic magmas extracted from mantle wedge. However, it has been shown by theoretical modeling and experimental studies that chemical variability/petrological diversity in TTG composition is not necessarily a factor of mineralogy and composition of source rock, the depth of melting, and the melting reactions but are equally governed by physical processes through which the melt migrates and segregates from its partially molten host (Jackson et al. 2005; Rushmer and Jackson 2008).

The second episodic magmatic event $(\sim 2.6-2.1$ $\mathrm{Ga}$ ) is represented by the TTG, felsic volcanic associated with greenstone belt and K-rich granites from the area (Mondal et al. 1998, 2002; Kaur et al. 2014, 2016; Singh and Slabunov 2015, 2016; Verma et al. 2016; Joshi et al. 2016). This marks another major crustal growth episode in the Bundelkhand region. These TTG gneisses and K-rich granites are also conjectured as partial melting of lower thickened crust. Verma et al. (2016) suggested that these rocks generated similarly through partial melting of thickened lower crust in a subduction setting.

The third magmatic episode $(2.0-0.9 \mathrm{Ga})$ in the Bundelkhand craton is marked by the giant quartz veins and mafic to ultramafic dykes (Sarkar et al. 1997; Sharma and Rahman 2000; Rao et al. 2005; Pradhan et al. 2012; Radhakrishna et al. 2013). The quartz veins/quartz reefs are believed to have generated by syntectonic hydrothermal activity (Pati et al. 2007) or by precipitation of quartz during a later wide scale extensional event (Bhattacharya and Singh 2013).

More extensive and intensive investigations are needed on the episode of magmatic activity in the Bundelkhand craton as the magmatism in the area is characterized by continuity rather than episodes. 


\subsection{Implication for geodynamic setting of Bundelkhand craton}

The geodynamic setting of the Bundelkhand rocks spanning from Paleo-Mesoarchean through Neoarchean to Paleoproterozoic which has undergone extensive magmatism and metamorphism is a long-standing issue in Indian geology. It remains to be robustly constrained due to lack of comprehensive data involving mineral chemistry, isotope and bulk chemistry and geochronological inputs. Nonetheless based on available data, it is more or less agreed upon that this rock combination resulted in an active continental margin or island arc setting.

Sharma (1998) invoked an alternating extensional and compressional environment in the tectonomagmatic evolution of the Bundelkhand carton wherein the extensional regime resulted in the evolution of volcano sedimentary greenstone belts and opening of the basins and the compressional regime resulted in the partial melting of mantle wedge resulting in generation of TTG.

Malviya et al. (2006) based on their study on metamorphosed pillow lava and basaltic komatite from Mauranipur area have commented that this volcano sedimentary greenstone belt has resulted from subduction-related compressional environment and the supracrustal units are remnants of suprasubduction crust of island arcs tectonically accreted to the continent during arc-continent collision. TTG was later generated by partial melting of mafic crust in convergent environment and collision-related K-rich felsic magma was emplaced as granitic plutons post-dating the TTGs. Giant quartz veins according to them mark the late stage hydrothermal activity associated with final felsic intrusion event. They emphasize that the extensional regime ensued only after the final stage of felsic intrusion by a deep-seated mantle plume forming the rift-related marginal basins of Gwalior and Bijawar. The mafic dyke swarms are the last stage of event which took place along weak fractures generated by rifting. In the given context, with the recent report of TTG magmatism of 2.6 Ga by Verma et al. (2016) suggesting contemporaneous TTG and felsic magmatism from the regions further studies is a need.

Mohan et al. (2012) confirm the generation of Bundelkhand granitoids (diorites, TTG and granites) undoubtedly is subduction derived, but has generated in multi-stage processes in a supra-subduction zone regime. According to them, in the supra-subduction zone slab dehydration resulted generation of hydrous sub-arc mantle of basaltic source and the low pressure melting at moderate to shallow depths possibly in the lower part of thickened oceanic arc crust has resulted in the petrologically diverse suite of rock in the Bundelkhand craton. The association of the mafic ultramafic units and metasedimentary belts with the TTGs to them represents a subduction accretion-collision of microblocks. The Neoarchean and early Paleoproterozoic collision related metamorphism and intrusion of crustally derived granitic melts is the final event of cratonization according to their model.

Large-scale partial melting of crustal materials and widespread metamorphism has been witnessed by Bundelkhand craton is usually envisaged to have been provided by intrusions and underplating of large volume of mantle derived magma which acts as the heat source required for melting to ensue. Variety of environments like hotspots driven by mantle plumes, continental rift environments, subduction related tectonic settings, continental collisional belts can provide the environment required for emplacement of sufficient amount of mantlederived magma.

Provided these TTGs were formed above hotspots as proposed by Smithies et al. (2009), (i.e., melting at base of a thick oceanic plateau crust heated by an upwelling mantle plume), these rocks would have been emplaced in a sequence of mantle plume related ultramafic to mafic rocks including komatiites, continental flood basalts, dyke swarms and layered intrusions (Ernst et al. 2008). No such plume-related magmatism has been reported from Bundelkhand craton nor is there a global record of plume activity in the Archaean times (Ernst and Bleeker 2010). Therefore, invoking a plume model to account for generation of Paleo-Mesoarchean TTGs in the Bundelkhand region seems inappropriate.

A continental rift environment is not plausible for the Bundelkhand craton as there is lack of alkali intrusive (syenite, nepheline syenite, etc.) of PaleoMesoarchean age expected to be associated with rifting (Zhao et al. 2001).

Martin et al. (2014) and Moyen and Martin (2012) through their work displayed that elevated $\mathrm{MgO}$ content, $\mathrm{Mg} \#$ values, and high $\mathrm{Cr}$ and $\mathrm{Ni}$ concentrations are the signatures to look for if the TTG were produced through partial melting of subducting or subducted oceanic crust or oceanic plateau materials. However the Paleo-Mesoarchean 
(a)

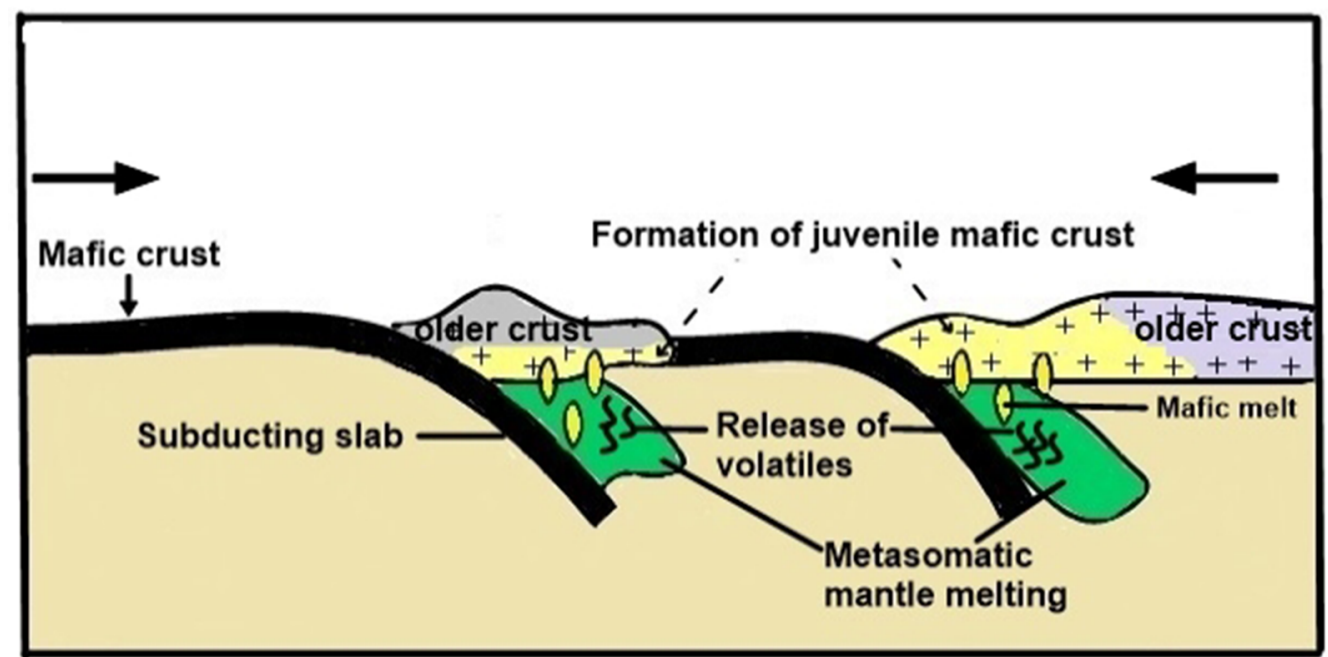

(b)

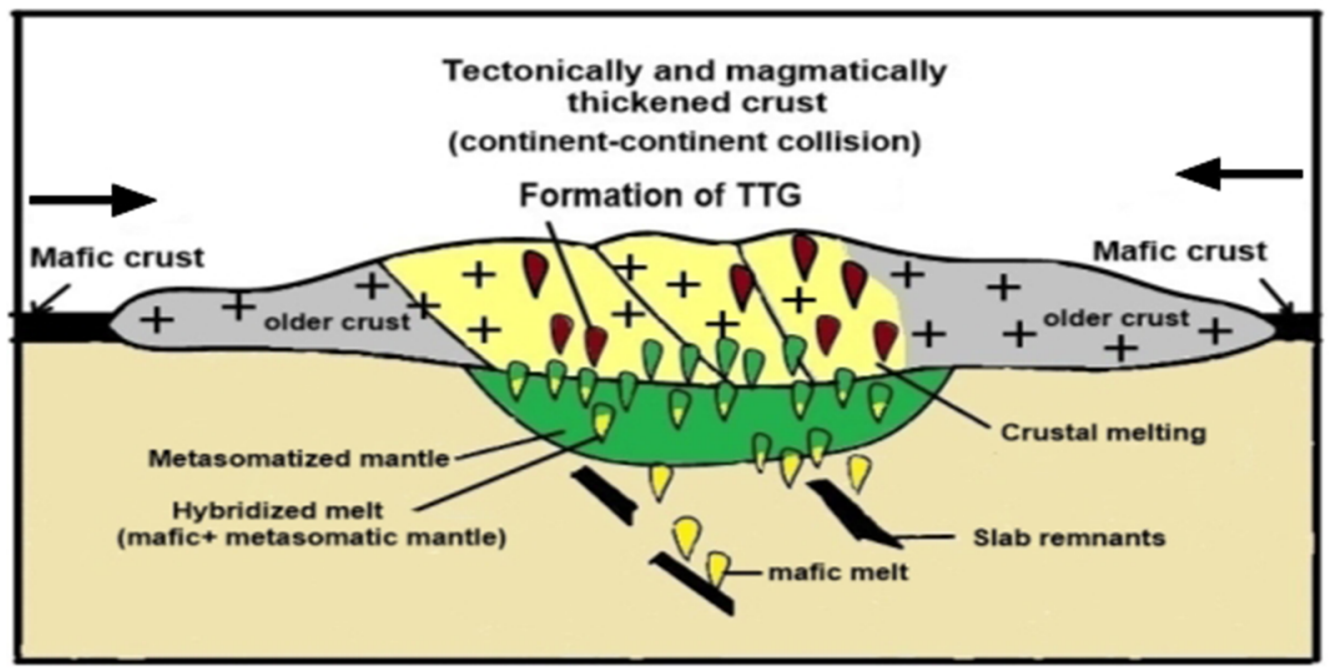

(c)

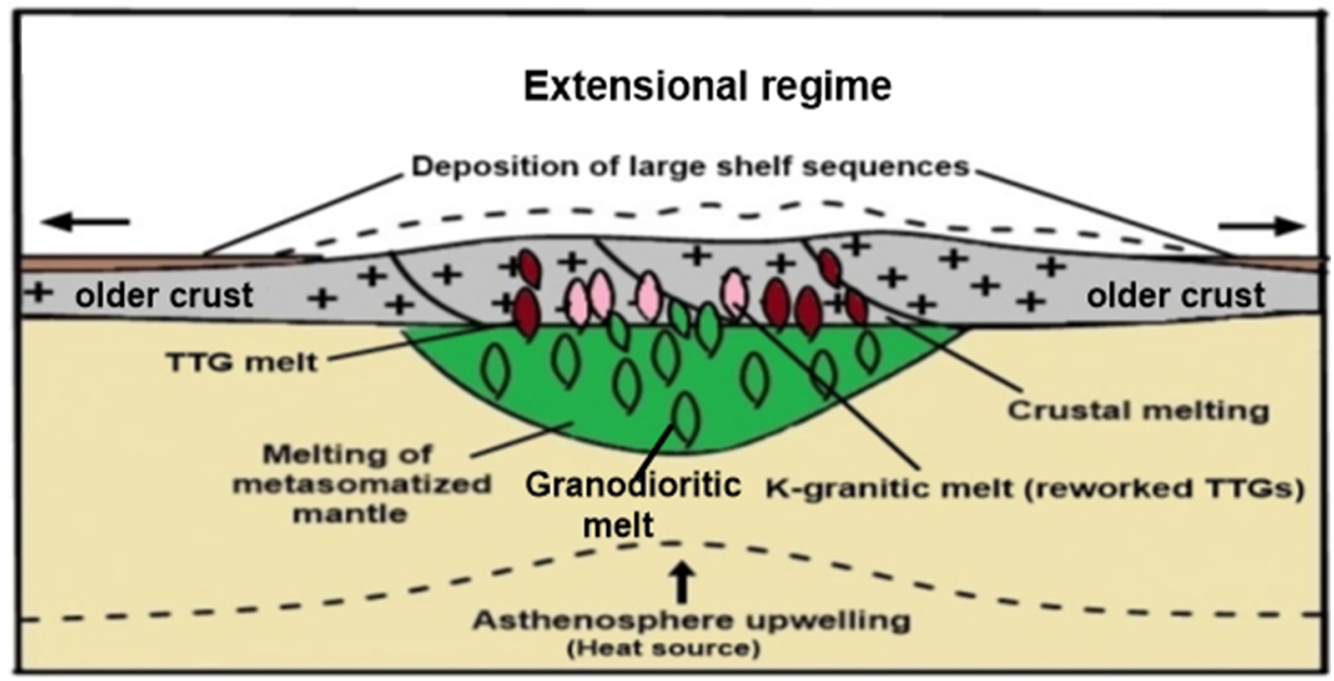


TTG rocks in the Bundelkhand region have no obvious geochemical signatures indicating enhanced melt-peridotite interaction (present study; Mohan et al. 2012; Kaur et al. 2016). Moreover, the Neoarchean TTG and K-rich granites from the region are rather the reworking products of Mesoarchean crustal materials (enriched mafic rocks plus previously emplaced felsic TTG), instead of juvenile addition to the crust as implied by the zircon Hf isotopic compositions (Kaur et al. 2016). This rules out that these TTGs were generated in subduction related settings (continental or island arcs, thickened arc systems and accretionary orogens), where juvenile mafic rocks act as source rocks (Martin et al. 2014).

In view of these findings, a continental collision setting is likely to have produced the PaleoMesoarchean TTG gneisses in the Bundelkhand craton. Continental collisional zones as primary sites for net continental crustal growth have been discussed by a number of workers (Niu et al. 2007, 2013; Mo et al. 2008; Niu and O'Hara 2009). It addresses the shortcomings of the standard island arc-model (Taylor 1967, 1977) and abandons the need of mantle plumes for episodic crustal growth (Stein and Hofmann 1994; Abbott and Mooney 1995; Pearson et al. 2007).

In our view, the Precambrian basement of the Bundelkhand craton is composed of two major kind of terrane: a high grade metamorphic terrane comprising of tonalite, trondhjemite, granodiorites,

Figure 16. A schematic diagram illustrating the proposed geodynamic setting for the evolution of TTG and associated K-granites in the Bundelkhand craton. Stage (a): During this stage, subduction takes place with possible episodic breakoff of the slab resulting in a generation (i) juvenile mafic crust over a long period of time and (ii) metasomatism of the overlying mantle due to volatiles released by subducting slab. Stage (b): The first stage ultimately leads to closure of an ocean basin and wielding of two proto-continental blocks (continental collision). At this stage, TTG crust formation takes place from the magma generated by partial melting of mafic lower crust triggered by the thickening of crust due to amalgamation. Stage (c): In the late- to post-collisional stage owing to thermal relaxation and extension, melting of the previously generated TTG crust ensues resulting in generation of the K-granites. During both syn collisional and late collisional stages, significant interaction between the mafic melts, TTG crust and metasomatised mantle melt also generates compositionally hybrid granitoid melt. These granitoids are characterized by coeval involvement of metasomatized mantle sources, and intracrustal melting as discussed in Laurent et al. (2014) for modern collisional granitoids. supracrustal rocks (ultramafic to mafic igneous rocks and sedimentary rocks with BIF) and a granitic terrane with no metamorphism all spanning a duration from 3.5 to 2.6 Ga. All of these rocks experienced a granulite facies metamorphism at $\sim 2.7$ to $2.4 \mathrm{Ga}$. The contemporaneous plutonic magmatism $(2.6-2.5 \mathrm{Ga})$ and the high grade metamorphism of $(2.7-2.4 \mathrm{Ga})$ as reported by Saha et al. (2011) indicate an intensive tectonothermal event (probably an orogenic event) in the late Neoarchean through the Bundelkhand craton. The associated high K-calc-alkaline granites favour this possibility. Cratonization of the Bundelkhand craton started with collision of micro-continental blocks with $\sim 3.6$ Ga crustal nuclei.

The Paleo-Mesoarchean TTG granitoids in the Bundelkhand craton were generated through partial melting of Eoarchean enriched mafic crustal sources at different depths coupled with low pressure crystal fractionation, which requires significant crustal thickening through micro-continental collision (Nutman et al. 2007). The K-rich granites with their intrusive contact with the TTG gneisses and younger age, represent the last pulse of Archaean magmatism in the Bundelkhand craton. These K-rich granites have formed by remelting of Paleo-Mesoarchean TTGs or mafic crustal materials in an extensional/non-compressional environment associated with a post-orogenic or postcollisional stage. A conceptual cartoon illustrating the proposed geodynamic environment corresponding to evolution of TTGs and K-granites of the Bundelkhand craton is shown in figure 16.

The melting of the Paleo-Mesoarchean mafic crust may have been triggered by melts rising from the upwelling mantle, which also modified the compositions of these melts by different degrees resulting in hornblende bearing granites, biotite bearing granites and leucogranites as reported by Mondal and Zainuddin (1996) from the Bundelkhand craton. Arndt (2013) has suggested that the variations in the composition and mineralogy of the source (including the proportion of juvenile magma and reworked crustal rocks), the composition of incoming magmas, the degree of partial melting, and the extent of fractionation crystallisation in crustal magma chambers can all contribute to the diversity of composition of the granitoids. The reported variation of initial Zircon Hf isotopic compositions as discussed by Saha et al. (2016) and Kaur et al. (2016) from TTG and granitoids from Bundelkhand craton is consistent with an increase in reworking processes associated with crustal 
thickening during collision and melting of the mantle sources. The dyke swarms and the quartz reefs and the marginal basins of Gwalior and Bijawar of this region can be associated with the extensional event which resulted in voluminous potassic granite plutons. However based on the available data from the region, it is hard to precisely constrain the details and configuration of the continental collision model for generation of TTG and associated rocks from the Bundelkhand craton.

We also need to take care of the fact that the Precambrian tectonic styles for continental collision belts are quite different from modern day continental belts as they were formed over a hotter mantle which rendered them to be mechanically weak (Sizova et al. 2014, 2015). This ensued frequent slab break off resulting in upwelling and subsequent melting of mantle. Likewise, Johnson et al. (2017) have advocated a multi-stage process for production and stabilization of the first continents coupled with high geothermal gradient which is incompatible with modern style plate tectonics. They favour formation of TTG near base of thick basaltic crust, hence subduction was not required to produce TTGs in the early Archaean Eon and emphasizes that arc-like signature was inherited from an ancestral source lineage.

\section{Conclusion}

The geochemical studies of the TTG and K-rich granites of the Bundelkhand craton reveal the following:

- The TTG are composed of recrystallized serrated quartz, large plagioclase crystals that are highly sericitized, biotite, hornblende and minor K-feldspar. The K-rich granites are composed of minerals that have a preferred orientation due to being sheared and are predominated by K-feldspar, biotites, recrystallized quartz and unaltered plagioclase.

- The TTGs and K-rich granites of Bundelkhand craton have a plagioclase composition that varies from $\mathrm{X}_{\mathrm{Ab}}=0.70-0.80$ and $\mathrm{X}_{\mathrm{Ab}}=0.73-0.80$, respectively. The K-feldspars of both the rock types possess near end member composition of $\mathrm{Or}_{0.96-0.99}$. Amphiboles of the TTGs are calcic $(\mathrm{Ca}=1.88-1.93$ atoms per formula unit) and are hastingsite. The $\mathrm{Al}$ in Hornblende barometer produced an average crystallization pressure of 5.94 kbar and calculated temperatures using the
Hornblende-Plagioclase geothermometer ranges from 757 to $777^{\circ} \mathrm{C}$. Biotites of both the TTGs and K-rich granites are representative of solid solution of annite-siderophyllite end members.

- The TTG rocks of Bundelkhand craton exhibit geochemical characteristics of other worldwide known TTG including $\mathrm{Al}_{2} \mathrm{O}_{3}$ contents of 13.4917.04 wt\%; $\mathrm{Na}_{2} \mathrm{O} / \mathrm{K}_{2} \mathrm{O}$ ratios of $1.28-3.89$, low concentration of heavy REE with Y contents of 5-42 ppm and $\mathrm{Yb}=0.3-0.5 \mathrm{ppm}$ leading to high $\mathrm{Sr} / \mathrm{Y}$ ratios (4.9-98) and $\mathrm{La} / \mathrm{Yb}=15-30$, fractionated REE patterns $\left(\mathrm{La} / \mathrm{Yb}_{\mathrm{CN}}=15-30\right)$, negative anomaly of $\mathrm{Nb}$. These geochemical characteristics have thus been interpreted as having formed by partial melting of the hydrous basaltic crust at pressures and depths where garnet and amphibole were stable phases in the late Archaean continental collisional setting.

- K-rich granites of the Bundelkhand craton differ from their TTG counterparts in having elevated concentrations of incompatible elements like Zr, Th and REE. They however share some similar geochemical compositions including fractionated REE patterns $\left(\mathrm{La} / \mathrm{Yb}_{\mathrm{CN}}=10-27\right)$, negative anomaly of $\mathrm{Nb}$ and have thus been interpreted to have formed by partial melting of the TTG (and greenstones)/mafic crust.

- Two-stage continental accretion (at 3.59-3.33 and 3.2-3.0 Ga) and reworking (at 2.5-1.9 Ga) occurred in the Bundelkhand craton from Archaean to Paleoproterozoic. Our study leads us to propose the development of a continental collisional tectonic regime in the ArchaeanPaleoproterozoic for the development of the Bundelkhand craton.

\section{Acknowledgements}

Ashima Saikia acknowledges R\&D grant for promotion of research, University of Delhi and CSIR Grant vide Project No. 24(0317)/12/EMR-II for carrying out this work.

\section{References}

Abbott D and Mooney W 1995 The structural and geochemical evolution of the continental crust: Support for the oceanic plateau model of continental growth; Rev. Geophys. 33(S1) 231-242.

Abdel-Rahman A F M 1994 Nature of biotites from alkaline, calc-alkaline and peraluminous magmas; J. Petrol. 35 525-541. 
Absar N, Raza M, Roy M, Naqvi S M and Roy A K 2009 Composition and weathering conditions of Paleoproterozoic upper crust of Bundelkhand craton, central India: Records from geochemistry of clastic sediments of $1.9 \mathrm{Ga}$ Gwalior Group; Precamb. Res. 168(3) 313-329.

Arndt N T 2013 The formation and evolution of the continental crust; Geochem. Perspec. 2(3) 405.

Atherton M P and Petford N 1993 Generation of sodium-rich magmas from newly underplated basaltic crust; Nature 362 144-146.

Balaram V, Saxena V K, Manikyamba C and Ramesh S L 1990 Determination of rare earth elements in Japanese rock standards by inductively coupled plasma mass spectrometry; Atomic Spectroscopy 11(1) 19-23.

Barker F 1979 Trondhjemites: Definition, environment and hypotheses of origin; In: Trondhjemites, Dacites and Related Rocks (ed.) Barker F; Elsevier, Amsterdam, pp. $1-12$.

Basu A K 1986 Geology of parts of the Brundelkhand granite massif central India; Rec. Geol. Surv. India 117(2) $61-124$.

Basu A K 2001 Some characteristics of the Precambrian crust in the northern part of central India; Geol. Surv. India Spec. Publ. 55 181-204.

Bhattacharya A R and Singh S P 2013 Proterozoic crustal scale shearing in the Bundelkhand massif with special reference to quartz reefs; J. Geol. Soc. India 82(5) 474.

Blundy J D and Holland T J B 1990 Calcic amphibole equilibria and a new amphibole-plagioclase geothermometer; Contrib. Mineral. Petrol. 104 208-224.

Champion D C and Sheraton J W 1997 Geochemistry and $\mathrm{Nd}$ isotope systematics of Archaean granites of the Eastern Goldfields, Yilgarn Craton, Australia: Implications for crustal growth processes; Precamb. Res. 83(1-3) 109 132.

Champion D C and Smithies R H 1999 Archaean granites of the Yilgarn and Pilbara cratons, western Australia: Secular changes; In: The Origin of Granites and Related Rocks - Fourth Hutton Symposium Abstracts Doc (ed.) Barbarin B, BRGM 290, 137p.

Condie K C 2005 TTGs and adakites: Are they both slab melts? Lithos 80(1) 33-44.

Crawford A R 1970 The Precambrian geochronology of Rajasthan and Bundelkhand, northern India; Can. J. Earth Sci. 7(1) 91-110.

Deb M, Thorpe R and Krstic D 2002 Hindoli group of rocks in the eastern fringe of the Aravalli-Delhi Orogenic Belt - Archean Secondary Greenstone Belt or Proterozoic supracrustals? Gondwana Res. 5(4) 879-883.

Deer W A, Howie R A and Zussman J 1992 An introduction to the rock forming minerals; ELBS Publication, UK, $696 \mathrm{p}$.

Drummond M S and Defant M J 1990 A model for trondhjemite-tonalite-dacite genesis and crustal growth via slab melting: Archean to modern comparisons; J. Geophys. Res.: Solid Earth 95(B13) 21503-21521.

Ernst R and Bleeker W 2010 Large igneous provinces (LIPs), giant dyke swarms, and mantle plumes: Significance for breakup events within Canada and adjacent regions from 2.5 Ga to the Present; Can. J. Earth Sci. 47(5) 695-739.

Ernst R E, Wingate M T D, Buchan K L and Li Z X 2008 Global record of 1600-700 Ma Large Igneous Provinces
(LIPs): Implications for the reconstruction of the proposed Nuna (Columbia) and Rodinia supercontinents; Precamb. Res. 160(1) 159-178.

Ghosh J G 2004 3.56 Ga tonalite in the central part of the Bastar craton, India: Oldest Indian date; J. Asian Earth Sci. 23(3) 359-364.

Foley S 2008 A trace element perspective on Archean crust formation and on the presence or absence of Archean subduction; Geol. Soc. Am. Spec. Papers 440 31-50.

Foley S, Tiepolo M and Vannucci R 2002 Growth of early continental crust controlled by melting of amphibolite in subduction zones; Nature 417(6891) 837-840.

Haldar D and Ghosh R N 2000 Eruption of Bijawar lava: An example of Precambrian volcanicity under stable cratonic conditions; Spec. Publ. Geol. Surv. India 57 151-170.

Halla J, van Hunen J, Heilimo E and Hölttä P 2009 Geochemical and numerical constraints on Neoarchean plate tectonics; Precamb. Res. 174(1) 155-162.

Hammerstrom J M and Zen E-An 1986 Aluminium in hornblende: An empirical igneous geobarometer; Am. Mineral. 71 1297-1313.

Heilimo E, Halla J and Hölttä P 2010 Discrimination and origin of the sanukitoid series: Geochemical constraints from the Neoarchean western Karelian Province (Finland); Lithos 115(1) 27-39.

Hollister L S, Grissom G C, Peters E K, Stowell H H and Sisson V B 1987 Confirmation of the empirical correlation of al in hornblende with pressure of solidification of clacalkaline plutons; Am. Mineral. 72 231-239.

Huang H, Niu Y, Nowell G, Zhao Z, Yu X, Zhu D C, Mo X and Ding S 2014 Geochemical constraints on the petrogenesis of granitoids in the East Kunlun Orogenic belt, northern Tibetan Plateau: Implications for continental crust growth through syn-collisional felsic magmatism; Chem. Geol. 370 1-18.

Irvine T N and Baragar W R A 1971 A guide to the geochemical classification of the common volcanic rocks; Can. J. Earth Sci. 8 523-548.

Jackson M D, Gallagher K, Petford N and Cheadle M J 2005 Towards a coupled physical and chemical model for tonalite-trondhjemite-granodiorite magma formation; Lithos 79(1) 43-60.

Jayananda M, Chardon D, Peucat J J and Capdevila R 2006 $2.61 \mathrm{Ga}$ K-rich granites and crustal reworking in the western Dharwar craton, southern India: Tectonic, geochronologic and geochemical constraints; Precamb. Res. 150(1) $1-26$.

Jayananda M, Chardon D, Peucat J J and Fanning C M 2015 Paleo-to Mesoarchean TTG accretion and continental growth in the western Dharwar craton, southern India: Constraints from SHRIMP U-Pb zircon geochronology, whole-rock geochemistry and Nd-Sr isotopes; Precamb. Res. $268295-322$.

Johnson T E, Brown M, Gardiner N J, Kirkland C L and Smithies R H 2017 Earth's first stable continents did not form by subduction; Nature $\mathbf{5 4 3}$ 239-242.

Joshi K B, Bhattacharjee J, Rai G, Halla J, Ahmad T, Kurhila M, Heilimo E and Choudhary A K 2016 The diversification of granitoids and plate tectonic implications at the Archaean-Proterozoic boundary in the Bundelkhand Craton, central India; Geol. Soc. London Spec. Publ. 449 123-157. 
Kaur P, Zeh A and Chaudhri N 2014 Characterisation and $\mathrm{U}-\mathrm{Pb}-\mathrm{Hf}$ isotope record of the $3.55 \mathrm{Ga}$ felsic crust from the Bundelkhand craton, northern India; Precamb. Res. $255236-244$.

Kaur P, Zeh A, Chaudhri N and Eliyas N 2016 Unravelling the record of Archaean crustal evolution of the Bundelkhand Craton, northern India using $\mathrm{U}-\mathrm{Pb}$ zircon-monazite ages, $\mathrm{Lu}-\mathrm{Hf}$ isotope systematics, and whole-rock geochemistry of granitoids; Precamb. Res. 281 384-413.

Kay R W and Kay S M 1993 Delamination and delamination magmatism; Tectonophys. 219(1-3) 177-189.

Kovalenko A, Clemens J D and Savatenkov V 2005 Petrogenetic constraints for the genesis of Archaean sanukitoid suites: Geochemistry and isotopic evidence from Karelia, Baltic Shield; Lithos 79(1) 147-160.

Kumar S, Yi K, Raju K, Pathak M, Kim N and Lee T H 2011 SHRIMP U-Pb geochronology of felsic magmatic lithounits in the central part of Bundelkhand Craton, central India; In: 7th Hutton Symposium on Granites and Related Rocks, Avila, Spain, 83.

Laurent O, Martin H, Moyen J F and Doucelance R 2014 The diversity and evolution of late-Archean granitoids: Evidence for the onset of 'modern-style' plate tectonics between 3.0 and $2.5 \mathrm{Ga}$; Lithos 205 208-235.

Leake B E, Woolley A R, Arps C E S and Birch W D 1997 Nomenclature of amphiboles: Report of the subcommittee on amphiboles of the international mineralogical association commission on new mineral names; Min. Mag. 61 295-321.

Lobach-Zhuchenko S B, Rollinson H, Chekulaev V P, Savatenkov V M, Kovalenko A V, Martin H, Guseva N S and Arestova N A 2008 Petrology of a Late Archaean, highly potassic, sanukitoid pluton from the Baltic Shield: Insights into Late Archaean mantle metasomatism; $J$. Petrol. 49(3) 393-420.

Macpherson C G, Dreher S T and Thirlwall M F 2006 Adakites without slab melting: High pressure differentiation of island arc magma, Mindanao, the Philippines; Earth Planet. Sci. Lett. 243(3) 581-593.

McDonough W F and Sun S S 1995 The composition of the Earth; Chem. Geol. 120(3-4) 223-253.

Malviya V P, Arima M, Pati J K and Kaneko Y 2004 First report of metamorphosed pillow lava in central part of Bundelkhand craton - an island arc setting of possible late Archaean age; Gondwana Res. 7 1338-1340.

Malviya V P, Arima M and Kaneko Y 2006 Petrology and geochemistry of metamorphosed basaltic pillow lava and basaltic komatiite in the Mauranipur area: Subduction related volcanism in the Archean Bundelkhand craton, central India; J. Min. Petrol. Sci. 101(4) 199-217.

Maniar P D and Piccoli P M 1989 Tectonic discrimination of granitoids; GSA Bull. 101 635-643.

Manya S, Maboko M A H and Nakamura E 2007 Geochemistry of high- $\mathrm{Mg}$ andesite and associated adakitic rocks in the Musoma-Mara Greenstone Belt, Northern Tanzania: Possible evidence for Neoarchaean ridge subduction? Precamb. Res. 159 241-259.

Martin H 1999 Adakitic magmas: Modern analogues of Archaean granitoids; Lithos 46(3) 411-429.

Martin H and Moyen J F 2005 The Archaean-Proterozoic transition: Sanukitoid and Closepet type magmatism; Min. Soc. Poland Spec. Papers 26 57-67.
Martin H, Moyen J F, Guitreau M, Toft J B and Pennec J L L 2014 Why Archean TTG cannot be generated by MORB melting in subduction zones; Lithos 198-199 113.

Meert J G, Pandit M K, Pradhan V R and Kamenov G 2011 Preliminary report on the paleomagnetism of $1.88 \mathrm{Ga}$ dykes from the Bastar and Dharwar cratons, peninsular India; Gondwana Res. 20(2) 335-343.

Miller C F, McDowell S M and Mapes R W 2003 Hot and cold granites? Implications of zircon saturation temperatures and preservation of inheritance; Geology 31(6) 529-532.

Mohan M R, Singh S P, Santosh M, Siddiqui M A and Balaram V 2012 TTG suite from the Bundelkhand Craton, central India: Geochemistry, petrogenesis and implications for Archean crustal evolution; J. Asian Earth Sci. $5838-50$.

Mondal M E A, Goswami J N, Deomurari M P and Sharma K $\mathrm{K} 2002$ Ion microprobe ${ }^{207} \mathrm{~Pb} /{ }^{206} \mathrm{~Pb}$ ages of zircons from the Bundelkhand massif, northern India: Implications for crustal evolution of the Bundelkhand-Aravalli protocontinent; Precamb. Res. 117(1) 85-100.

Mondal M E A, Sharma K K, Rahman A and Goswami J N 1998 Ion microprobe ${ }^{207} \mathrm{~Pb} /{ }^{206} \mathrm{~Pb}$ zircon ages for gneissgranitoid rocks from Bundelkhand massif: Evidence for Archaean components; Curr. Sci. 74 70-74.

Mondal M E A and Zainuddin S M 1996 Evolution of the Archean-Paleoproterozoic Bundelkhand Massif, central India - evidence from granitoid geochemistry; Terra Nova 8(6) 532-539.

Mo X, Niu Y, Dong G, Zhao Z, Hou Z, Zhou S and Ke S 2008 Contribution of syncollisional felsic magmatism to continental crust growth: A case study of the Paleogene Linzizong volcanic succession in southern Tibet; Chem. Geol. 250(1) 49-67.

Moyen J F 2009 High Sr/Y and La/Yb ratios: The meaning of the 'adakitic signature'; Lithos 112(3) 556-574.

Moyen J F 2011 The composite Archaean grey gneisses: Petrological significance, and evidence for a non-unique tectonic setting for Archaean crustal growth; Lithos 123(1) 21-36.

Moyen J F and Martin H 2012 Forty years of TTG research; Lithos 148 312-336.

Moyen J F, Martin H, Jayananda M and Auvray B 2003 Late Archaean granites: A typology based on the Dharwar Craton (India); Precamb. Res. 127(1) 103-123.

Moyen J F, Nédélec A, Martin H and Jayananda M 2003 Syntectonic granite emplacement at different structural levels: The Closepet granite, South India; J. Struct. Geol. 25(4) 611-631.

Naqvi S M and Rogers J J W 1987 Precambrian Geology of India; Oxford University Press, New York, 223p.

Niu Y L, Mo X, Dong G, Zhao Z, Hou Z, Zhou S and Ke S 2007 Continental collision zones are primary sites of net continental crustal growth: Evidence from the Linzizong volcanic succession in southern Tibet; EOS Trans. Am. Geophys. Union 88(52) (Fall Meeting, Supplement Abstract V34A-01).

Niu Y and O'Hara M J 2009 MORB mantle hosts the missing $\mathrm{Eu}$ ( $\mathrm{Sr}, \mathrm{Nb}, \mathrm{Ta}$ and $\mathrm{Ti}$ ) in the continental crust: New perspectives on crustal growth, crust-mantle differentiation and chemical structure of oceanic upper mantle; Lithos 112(1) 1-17. 
Niu Y, Zhao Z, Zhu D C and Mo X 2013 Continental collision zones are primary sites for net continental crust growth a testable hypothesis; Earth-Sci. Rev. 127 96-110.

Nutman A P, Friend C R, Horie K and Hidaka H 2007 The Itsaq gneiss complex of southern west greenland and the construction of eoarchaean Crust at convergent pate boundaries; Dev. Precamb. Geol. 15 187-218.

O'connor J T 1965 A classification for quartz-rich igneous rocks based on feldspar ratios; US Geol. Sur. Professional Paper B $\mathbf{5 2 5}$ 79-84.

Oliveria M A, Dall'Agnol R and Scaillet B 2010 Petrological constraints on crystallization conditions of Mesoarchean Sanukitoid rocks, southeastern Amazonian Craton, Brazil; J. Petrol. 51 2121-2148.

Pati J K 1999 Specialized thematic study of older enclaves (migmatites, gneisses and supracrustals) within the Bundelkhand Granitoid Complex (BUGC); Geol. Surv. India, (NR), Progress Report (FST 1997-1998), 25.

Pati J K, Patel S C, Pruseth K L, Malviya V P, Arima M, Raju S, Pati P and Prakash K 2007 Geology and geochemistry of giant quartz veins from the Bundelkhand Craton, central India and their implications; J. Earth Syst. Sci. 116(6) 497-510.

Pati J K, Raju S, Mamgain V D and Shanker R 1997 Gold mineralization in parts of Bundelkhand granitoid complex (BGC); Geol. Soc. India 50(5) 601-606.

Patiño-Douce A E 1996 Effects of pressure and $\mathrm{H}_{2} \mathrm{O}$ content on the composition of primary crustal melts; Trans. $R$. Soc. Edinburgh: Earth Sci. 87 11-21.

Patiño-Douce A E 2005 Vapour absent melting of tonalite at 15-32 kbar; J. Petrol. 46 275-290.

Patiño-Douce A E 1999 What do experiments tell us about the relative contributions of crust and mantle to the origin of granitic magmas? In: Understanding granites: Integrating new and classical techniques (eds) Castro A, Fernandez C and Vigneressese J L, Geol. Soc. London Spec. Publ. 168 55-75.

Pearce J A, Harris B W and Tindle A G 1984 Trace element discrimination diagrams for the tectonic interpretation of granitic rocks; J. Petrol. 25 956-983.

Pearson D G, Parman S W and Nowell G M 2007 A link between large mantle melting events and continent growth seen in osmium isotopes; Nature 449(7159) 202205.

Peccerillo A and Taylor S R 1976 Geochemistry of Eocene calc-alkaline volcanic rocks from the Kastamonu area, northern Turkey; Contrib. Mineral. Petrol. 58 63-81.

Pradhan V R, Meert J G, Pandit M K, Kamenov G, Gregory L C and Malone S J 2009 India's changing place in global Proterozoic reconstructions: A review of geochronologic constraints and Paleomagnetic poles from the Dharwar, Bundelkhand and Marwar cratons; J. Geodyn. 50(3-4) 224-242.

Pradhan V R, Meert J G, Pandit M K, Kamenov G and Mondal M E A 2012 Paleomagnetic and geochronological studies of the mafic dyke swarms of Bundelkhand craton, central India: Implications for the tectonic evolution and paleographic reconstructions; Precamb. Res. 198-199 51-76.

Purohit K K, Mukherjee P K, Saini N K, Khanna P P and Rathi M S 2006 Geochemical Survey of stream sediments from upper parts of Alaknanda, Mandakini,
Bhilangana and Bhagirathi Catchments, Garhwal Himalaya; Himalayan Geol. 27(1) 31-39.

Radhakrishna T, Chandra R, Srivastava A K and Balasubramonian G 2013 Central/eastern Indian Bundelkhand and Bastar cratons in the Palaeoproterozoic supercontinental reconstructions: A palaeomagnetic perspective; Precamb. Res. 226 91-104.

Ramakrishnan M and Vaidyanadhan R 2010 Geology of India; Geological Society of India Publication , 428p.

Rao J M, Rao G P, Widdowson M and Kelley S P 2005 Evolution of Proterozoic mafic dyke swarms of the Bundelkhand granite massif, central India; Curr. Sci. 88(3) 502-506.

Rapp R P, Watson E B and Miller C F 1991 Partial melting of amphibolites/eclogite and the origin of Archean trondhjemites and tonalities; Precamb. Res. 51(1-4) 125 .

Rapp R P, Shimizu N, Norman M D and Applegate G S 1999 Reaction between slab-derived melts and peridotite in the mantle wedge: Experimental constraints at 3.8 GPa; Chem. Geol. 160(4) 335-356.

Roy A B and Kröner A 1996 Single zircon evaporation ages constraining the growth of the Archaean Aravalli craton, northwestern Indian shield; Geol. Mag. 133(03) 333-342.

Rutter M J and Wyllie P J 1988 Melting of vapour-absent tonalite at $10 \mathrm{kbar}$ to simulate dehydration-melting in the deep crust; Nature 331(6152) 159-160.

Rushmer T and Jackson M 2008 Impact of melt segregation on tonalite-trondhjemite-granodiorite (TTG) petrogenesis; Trans. Roy. Soc. Edinburgh: Earth Sci. 97(04) 325-336.

Saha L, Pant N C, Pati J K, Upadhyay D, Berndt J, Bhattacharya A and Satynarayanan M 2011 Neoarchean highpressure margarite-phengitic muscovite-chlorite corona mantled corundum in quartz-free high- $\mathrm{Mg}, \mathrm{Al}$ phlogopitechlorite schists from the Bundelkhand craton, north central India; Contrib. Mineral. Petrol. 161(4) 511-530.

Saha L, Frei D, Gerdes A, Pati J K, Sarkar S, Patole V, Bhandari A and Nasipuri P 2016 Crustal geodynamics from the Archaean Bundelkhand Craton, India: Constraints from zircon U-Pb-Hf isotope studies; Geol. Mag. 153(01) 179 192.

Saini N K, Mukherjee P K, Rathi M S, Khanna P P and Purohit K K 1998 A new geochemical reference sample of granite (DG-H) from Dalhousie, Himachal Himalaya; J. Geol. Soc. India 52 603-606.

Saini N K, Mukherjee P K, Rathi M S and Khanna P P 2000 Evaluation of energy-dispersive X-ray fluorescence spectrometry in the rapid analysis of silicate rocks using pressed powder pellets; X-Ray Spectrometry 29(2) 166172.

Saini N K, Mukherjee P K, Khanna P P and Purohit K K 2007 A proposed amphibolite reference rock sample (AMH) from Himachal Pradesh; J. Geol. Soc. India 69799 802.

Sarkar A, Paul D K and Potts P J 1996 Geochronology and geochemistry of the Mid-Archaean trondhjemitic gneisses from the Bundelkhand craton, central India; Recent Res. Geol. 16 76-92.

Sarkar A, Trivedi J R, Gopalan K, Singh P N, Das A K and Paul D K 1984 Rb-Sr geochronology of Bundelkhand granitic complex in the Jhansi-Babina-Talbehat sector, 
UP, India; Indian J. Earth Sci., CEISM Seminar Volume, $64-72$.

Sarkar A, Ghosh S, Singhai R K and Gupta S N 1997 Rb-Sr geochronology of the Dargawan sill: Constraint on the age of the type Bijawar sequence of central India; In: International Conference on Isotopes in Solar System 5 100-101.

Sharma K K 1998 Geological evolution and crustal growth of Bundelkhand craton and its relict in the surrounding regions, North Indian Shield; In: The Indian Precambrian, Paliwal B S (ed). Scientific Publishers, Jodhpur, 1593 3343.

Sharma R S 2009 Cratons of the Indian shield. Springer Berlin Heidelberg, pp. 41-115.

Sharma K K and Rahman A 2000 The Early ArchaeanPaleoproterozoic crustal growth of the Bundelkhand craton, northern Indian shield; In: Crustal Evolution and Metallogeny in the Northwestern Indian Shield, Narosa Publishing House, New Delhi, pp. 51-72.

Sharma K K and Rahman A 1995 Occurrence and petrogenesis of Loda Pahar trondhjemitic gneiss from Bundelkhand craton, central India: Remnant of an early crust; Curr. Sci. 69 613-617.

Singh S P, Singh M M, Srivastava G S and Basu A K 2007 Crustal evolution in Bundelkhand area, central India; $J$. Himal. Geol. 28(2) 79-101.

Singh V K and Slabunov A 2015 The central Bundelkhand Archaean greenstone complex, Bundelkhand craton, central India: Geology, composition, and geochronology of supracrustal rocks; Intern. Geol. Rev. 57(11-12) 13491364.

Singh V K and Slabunov A 2016 Two types of Archaean supracrustal belts in the Bundelkhand craton, India: Geology, geochemistry, age and implication for craton crustal evolution; J. Geol. Soc. India 88(5) 539-548.

Sizova E, Gerya T and Brown M 2014 Contrasting styles of Phanerozoic and Precambrian continental collision; Gondwana Res. 25(2) 522-545.

Sizova E, Gerya T, Stüwe K and Brown M 2015 Generation of felsic crust in the Archean: A geodynamic modeling perspective; Precamb. Res. 271 198-224.

Skjerlie K P and Johnston A D 1993 Fluid-absent melting behavior of an F-rich tonalitic gneiss at mid-crustal pressures: Implications for the generation of anorogenic granites; J. Petrol. 34(4) 785-815.

Smithies R H 2000 The Archaean tonalite-trondhjemitegranodiorite (TTG) series is not an analogue of Cenozoicadakite; Earth Planet. Sci. Lett. 182(1) 115-125.

Smithies R H and Champion D 2000 The archaean high-Mg diorite suite: Links to tonalite-trondhjemite-granodiorite magmatism and implications for early Archaean crustal growth; J. Petrol. 41 1653-1671

Smithies R H, Champion D C and Van Kranendonk M J 2009 Formation of Paleoarchean continental crust through infracrustal melting of enriched basalt; Earth Planet. Sci. Lett. 281(3) 298-306.

Smithies R H 2002 Archaean boninite-like rocks in an intracratonic setting; Earth Planet. Sci. Lett. 197(1) 1934.

Speer J A 1984 Micas in igneous rocks; In: Mineralogical, Society of America, Rev. Miner. 13 299-356.

Stein M and Hofmann A W 1994 Mantle plumes and episodic crustal growth, Nature 372(6501) 63-68.

Sun S S and McDonough W S 1989 Chemical and isotopic systematics of oceanic basalts: Implications for mantle composition and processes; Geol. Soc. London, Spec. Publ. 42(1) 313-345.

Sylvester P J 1994 Archean granite plutons; Dev. Precamb. Geol. 11 261-314.

Taylor S R 1967 The origin and growth of continents; Tectonophys. 4(1) 17-34.

Taylor S R 1977 Island arc models and the composition of the continental crust; In: Island arcs, deep sea trenches and back-arc basins (ed.) M Talwani, American Geophysical Union, Washington, DC, pp. 325-335.

Thompson A B 1996 Fertility of crustal rocks during anatexis; Trans. Roy. Soc. Edinburgh: Earth Sci. 87 1-10.

Upadhyay D, Chattopadhyay S, Kooijiman E, Mezger K and Berndt J 2014 Magmatic and metamorphic history of Paleoarchean tonalite-trondhjemite-granodiorite suite from the Singhbhum Craton, eastern India; Precamb. Res. 252 180-190.

Verma S K, Verma S P, Oliveira E P, Singh V K and Moreno J A 2016 LA-SF-ICP-MS zircon U-Pb geochronology of granitic rocks from the central Bundelkhand greenstone complex, Bundelkhand craton, India; J. Asian Earth Sci. $118125-137$.

Wang Q, McDermott F, Xu J F, Bellon $\mathrm{H}$ and Zhu Y T 2005 Cenozoic K-rich adakitic volcanic rocks in the Hohxil area, northern Tibet: Lower-crustal melting in an intracontinental setting; Geology 33(6) 465-468.

Watkins J M, Clemens J D and Treloar P J 2007 Archaean TTGs as sources of younger granitic magmas: Melting of sodic metatonalites at 0.6-1.2 GPa; Contrib. Mineral. Petrol. 154(1) 91-110.

Watson E B and Harrison T M 1983 Zircon saturation revisited: Temperature and composition effects in a variety of crustal magma types; Earth Planet. Sci. Lett. 64(2) 295-304.

Wolf M B and Wyllie P J 1994 Dehydration-melting of amphibolite at $10 \mathrm{kbar}$ : The effects of temperature and time; Contrib. Mineral. Petrol. 115(4) 369-383.

Zhao G, Wilde S A, Cawood P A and Sun M 2001 Archean blocks and their boundaries in the North China Craton: Lithological, geochemical, structural and $\mathrm{P}-\mathrm{T}$ path constraints and tectonic evolution; Precamb. Res. 107(1) $45-73$. 